\title{
Sustainability of non-residential buildings and relevance of main environmental impact contributors' variability. A case study of food retail stores buildings
}

\author{
Beatriz Gimeno-Frontera ${ }^{a}$, María Dolores Mainar-Toledo ${ }^{a}$, Aitana Sáez-de-Guinoa ${ }^{a}$, David
}

Zambrana-Vasquez $^{\mathrm{a}}$, Ignacio Zabalza Bribián ${ }^{* b}$

${ }^{a}$ Research Centre for Energy Resources and Consumption (CIRCE), CIRCE Building Campus Río Ebro, Mariano Esquillor Gómez, 15, 50018 Zaragoza, Spain

${ }^{b}$ Research Centre for Energy Resources and Consumption (CIRCE) - University of Zaragoza, CIRCE Building - Campus Río Ebro, Mariano Esquillor Gómez, 15, 50018 Zaragoza, Spain

\begin{abstract}
European tertiary sector represents about $13 \%$ of EU-28 final energy consumption. As an example, food retail stores sector amounts about 3\% of EU members' electricity consumption. Furthermore, currently, fluorinated gases, which are the most used refrigerants for space conditioning and refrigeration systems, involve $2 \%$ of EU emissions, having risen since 1990 by $60 \%$. Specifically, commercial refrigeration is responsible for $35 \%$ of EU-27 $\mathrm{CO}_{2}$-eq emissions related to refrigerants.
\end{abstract}

A methodology based on Life Cycle Assessment standards is presented in this study to assess the energy and environmental implications of non-residential buildings, adapted to particularities of food retail stores buildings, in terms of Primary Energy Demand, carbon footprint and water demand. Relying on a reference building, constructive improvements are tested and evaluated. Then a sensitivity analysis of several configurations of food retail stores are studied considering their building location, refrigerant typology and schedule. Results show that electricity and refrigerants are the main contributors and sensitive to potential improvements. In fact, static calculations reveal that a food retail store may involve, in terms of Global Warming Potential, about $800 \mathrm{kgCO}_{2}-\mathrm{eq} / \mathrm{m}^{2}$ year, more than 20 times higher than a regular building. Thus, future scenarios are estimated through a dynamic calculation methodology. Due to optimal dimensioning and configuration of the refrigeration system, together with refrigerant replacement, an $80 \%$ of Global Warming Potential minimization can be reached. Furthermore, temporal dynamic assessment can present a variability of environmental impacts estimation from static Life Cycle Assessment of more than 15\%, by considering a wider approach towards sustainability assessment of non-residential buildings.

\section{KEYWORDS}

Life Cycle Assessment, non-residential buildings, food retail stores buildings, energy efficiency, refrigeration systems, Global Warming Potential, Dynamic Life Cycle Assessment.

\footnotetext{
* Corresponding author: izabal@unizar.es
} 
NOMENCLATURE

\section{Acronyms}

ALR- Annual Leakage Rate

CED- Cumulative Energy Demand

DHW- Domestic Hot Water

DLCA- Dynamic Life Cycle Assessment

DX- Direct Expansion

EMAS- Eco-Management and Audit Scheme

EOL- End of Life

EPD- Environmental Product Declaration

EU- European Union

EU-27- European Union 27 Member States (from January 2007 to June 2013)

EU-28- European Union 28 Member States (from 1 July 2013)

F-gas- Fluorinated gases

GHG- Greenhouse Gas

GSHP- Ground Source Heat Pump

GWP- Global Warming Potential 
HFC- Hydrofluorocarbon

HVAC\&R- Heating, Ventilation, Air Conditioning and Refrigeration

IIR- International Institute of Refrigeration

LCA- Life Cycle Assessment

LCI- Life Cycle Inventory

MH- Metal Halide

MT- Medium Temperature

MS- Member State

MW- Mineral Wool

RSL- Reference Service Life

SCOP- Seasonal Coefficient of Performance

SEER- Seasonal Energy Efficiency Ratio

UN- United Nations 


\section{INTRODUCTION}

Non-residential buildings represent 25\% of European building stock, whereof about one third of useful floor space is represented by wholesale and retail buildings [1]. Commerce and public services represent about $12.5 \%$ of EU-28 final energy consumption, accounting for more than 150 Mtoe in 2016 [2]. More in detail, at Spanish level, services sector emitted in 2015 almost, $15.5 \mathrm{MtCO}_{2}$ - eq related to energy consumption [3] and represented about 30\% of national electrical intake [4], whereof commercial sector accounted one third. In fact, retail sector has been pointed as one of the priority sectors according to Regulation 1221/2009 of the European Parliament on the voluntary participation by organisations in a Community EcoManagement and Audit Scheme (EMAS) [5], detailed by the Commission Decision 2015/801 [6].

Regarding retail sector, food retail stores are considered the main electricity consumers [7]. Moreover, according to Galvez-Martos, J. L., 2013, food retail stores buildings may, at least, duplicate other commercial buildings' final energy intensity, such us office buildings which account for $100-200 \mathrm{kWh} / \mathrm{m}^{2}$ year [8]. The main energy-consuming facilities in food retail stores are perishable food refrigeration fixtures, being usually responsible for around half of the total electricity use, followed by illumination equipment that stands for about $20 \%$ of total energy consumption [9]. On the other hand, commercial refrigeration represented $13 \%$ of 2012 EU-27 refrigerant bank in terms of weight and was responsible for $22 \%$ of total EU-27 refrigerant emissions, with the release of more than 16,000 tonnes of refrigerants; furthermore, it accounted for 45,000 $\mathrm{ktCO}_{2}$ - eq, which implied $35 \%$ of $\mathrm{EU}-27 \mathrm{CO}_{2}$ - eq emissions related to refrigerants [10]. Hydro-fluorocarbon (HFC) refrigerants R404a and R134a, according to the nomenclature specified in ANSI/ASHRAE 34-2013 [11], represented, by the year 2012, 66\% and 13\%, respectively, of the refrigerant bank for commercial refrigeration, having become the most commonly used refrigerants in commercial 
refrigeration sector as of R22 and R12 were banned. Nowadays, several alternatives such as hydrocarbons, natural refrigerants or lower GWP HFC and HydroFluoroOlefin (HFO) fluids are being assessed. Paradoxically, ammonia has been the most used refrigerant in food processing industry for 100 years [12] and hydrocarbons were common refrigerants between the late XIX century and 1930 [13]. Natural refrigerants such as R744 $\left(\mathrm{CO}_{2}\right)$ and R717 (ammonia) represented 4\% of the bank in 2012 [10]; but it has been noted that, for example, between 2012 and 2015 the number of $\mathrm{CO}_{2}$-based stores in Europe has almost trebled, according to market trends [14].

Spanish retailers' environmental impact related to refrigerant leakages, per sales area, has been in a steady decline in recent years. According to the annual reports disseminated by the main hypermarket companies operating in Spain, they have decreased the direct impact related to refrigerants refill from more than $300 \mathrm{kgCO}_{2}-\mathrm{eq} / \mathrm{m}^{2}$ year during 2010 to less than $150 \mathrm{kgCO}_{2}-\mathrm{eq} / \mathrm{m}^{2}$ year in the year 2015 [15]. It should be noted that according to GalvezMartos, J. L., 2013, refrigerant refill quantity can be read as equal to leakage [8]. Instead, retailers who mainly own smaller stores, such as supermarkets, still report over $200 \mathrm{kgCO}_{2}$ $\mathrm{eq} / \mathrm{m}^{2}$ year direct impact in terms of annual refrigerant refill [15]. Against stand-alone commercial refrigeration, where Annual Leakage Rate (ALR) can account for between 1\% [16] and 5\% [17], supermarkets' direct and indirect systems ALR can range from 18\% and $12 \%$ respectively [17], or even reach 30\% [16]. Refrigerant leakages during building operation cannot be completely avoided, although minimization can be achieved.

Current trends are encouraging non-residential buildings' managers and more specifically retail stores managers to adapt their outlets to low energy buildings and rethink their running patterns. On the one hand, worldwide environmental situation has been promoting, in terms of regulation: i) international agreements, such as Montreal protocol [18]; ii) European decarbonisation directives towards 20-20-20 goals achievement, like 2012/27/EU regarding 
energy efficiency [19]; iii) EU Circular Economy Strategy facing 2030 [20]; iv) Best environmental management practices for commercial retail sector, consolidated by the voluntary participation by organisations in a EMAS Community, as defined in the Commission Decision (EU) 2015/801[6] and v) European F-gas regulation to reduce high Global Warming Potential (GWP) refrigerants, among other issues [21]. On the other hand, consumers' awareness has encouraged food retail companies to develop environmental friendly strategies [22]. As a result, for example, six of the principal food retail enterprises that operate in Spain have enrolled Global Compact initiative fostered by United Nations (UN), undertaking their social and environmental responsibility and facing innovative commitment plans [23]. As an example, the food retailer with the biggest market share in Spain declared to provide energy efficiency training to staff in every supermarket [24], which, according to Carbon Trust [25], can lead to higher $\mathrm{CO}_{2}$ - eq potential savings than other solutions such as doors on cabinets and LED lighting technology. At building level, there are many types of building certifications, such as Building Research Establishment Environmental Assessment Methodology (BREEAM) or Leadership in Energy and Environmental Design (LEED), contributing to the energy management improvement and the minimization of Greenhouse Gas (GHG) emissions, e.g., BREEAM certification achieved by Lidl Växjö in Sweden [26]. LEED certification has similar mandatory requirements to current European legislation regarding refrigerants and as an optional criterion, the use of environmental-friendly refrigerants can account for about $2 \%$ of total score [27].

Even so, available studies related to the application of global methodologies for environmental impact assessment of particular non-residential buildings, such as food retail stores buildings, have restricted scope and/or approach. In 2011, Target Zero programme published five guides in order to give advice on the 'Design and construction of sustainable, low and zero carbon buildings in the UK'. One of them focused on supermarkets, 
investigating operational carbon, modelled according to National Calculation Methodology (NCM), BREEAM assessments and embodied carbon, calculated following LCA Standards ISO 14040 and 14044 [28]. Nevertheless, this approach left out food refrigeration energy implications and refrigerants direct and indirect impacts. In terms of operational energy consumption, there are comprehensive studies, empirical and simulated, such as Braun et al., 2014 [29] and Spyrou et al., 2014 [30]. Furthermore, refrigeration fittings and refrigerants have been deeply analysed by specialized groups like the International Institute of Refrigeration (IIR), developing further assessment methodology [17].

Hence, this article presents a methodology based on LCA standards in order to estimate environmental implications of particular non-residential buildings, such as food retail stores buildings. The approach considers potential typological, temporal and spatial variables relevance evaluation in order to gauge the role of electricity consumption and refrigerant leakages. Thus, it is possible to perform a sensitivity analysis of environmental impact calculations of non-residential buildings and ease decision support towards their sustainability assessment, considering the relevance of the main impact contributors' variability within a dynamic approach.

\section{METHODOLOGY}

Standards ISO 14040:2006 [31] and 14044:2006 [32] stablish LCA framework, which has been adapted to buildings' specific evaluation through CEN/TC 350, developing EN 156431[33], -2[34], -3[35], -4[36], EN 15804 [37] and 15978 [38]. According to building stages standard classification, this study develops a cradle to grave approach. A methodological proposal for non-residential buildings' life cycle stages, adapted to food retail stores particularities, is described in Figure 1. From the stages shown in Figure 1, the following aspects have been considered: i) building materials (including thermal envelope and 
structure), HVAC\&R system and refrigerant's A1-A4 modules; ii) estimated resources consumption of construction process regarding module A5; iii) annual refrigerant leakages and consequent refrigerant refill within modules B1 and B2; iv) building materials and HVAC\&R systems replacement by products with the same features and technical specifications, in B4; v) operational energy and water use, in B6 and B7, respectively; vi) building materials and HVAC\&R systems EOL transport and processing within C2 and C3 modules and vii) EOL refrigerant leakages in C4. Figure 2, appends externalities and variables affecting building's performance in order to conduct calculations over the methodological approach proposed in Figure 1.

\subsection{Goal and scope definition}

This study aims to evaluate the environmental implications and potential relevance of variability among the current main impact contributors to food retail stores buildings, e.g., electricity and refrigerant leakages. The food retail store building becomes the functional unit considered and it is assessed for 50 years of Reference Service Life (RSL), fulfilling the design, space thermal conditions and edible refrigerated food conservation requirements for the year 2016. In order to obtain comparable results, calculations are presented related to sales area surface $\left(\mathrm{m}^{2}\right)$, the usual unit for indicators comparison in retail trade sector.

\subsection{Reference building selection and energy modelling}

The methodology described is deemed appropriate for non-residential buildings, particularly for food retail stores. A hypothetical representative stand-alone, single storey supermarket has been developed as reference building, relying on current building regulation and practices. The reference building has been modelled in Design Builder ${ }^{1}$ software (v.4.7) [39] in order to

\footnotetext{
${ }^{1}$ Design Builder Software Limited, www.designbuilder.co.uk
} 
perform the energy simulation through Energy Plus ${ }^{2}$ engine [40]. It should be noted that total energy consumption corresponds to electricity. The operational energy consumption breakdown (kWh/m²year) has been obtained: i) refrigeration fittings and electronic devices, ii) lighting, iii) space heating, iv) space cooling and v) Domestic Hot Water (DHW). In order to achieve reliable results on energy loads considering the variables involved and heat transfer related, simulations have been performed and the values obtained verified with enterprises' reports and scientific literature consulted for further analysis. Moreover, the reference building simulation has enabled to test the improvement opportunities potential.

\subsection{Boundaries of the system}

In accordance to the methodological approach presented in Figure 1, this study considers the main building materials, the heat pump and DHW boiler, refrigerant charge and leakages and the illumination system, as well as, operational energy and water consumption. Due to the variability and abundant literature available regarding refrigeration and air conditioning configuration systems, e.g., Cecchinato (2012) [41], this study does not accomplish a comprehensive study on HVAC\&R layout or configuration. Consequently, it assumes the minimization of heating and cooling demand, as well as, refrigeration thermal losses and the improvement of the lighting equipment, leaving out specific considerations on HVAC\&R configuration. In addition, related to display cabinets, it has been assumed a potential reduction of $20 \%$ of refrigeration thermal losses, which could be achieved reducing air infiltrations, e.g., through optimum air curtains [42] or even better results could be met with glass doors on vertical multi-deck shelves [43]. Refrigerated cabinets and shelves' embodied carbon, between 280 and $620 \mathrm{kgCO}_{2}-\mathrm{eq} / \mathrm{m}$ regarding length of display case [44], is not taken

\footnotetext{
${ }^{2}$ www.energyplus.net
} 
into account in this study due to: i) it has been demonstrated that their use phase represents more than $90 \%$ of their environmental impacts (approx. 93\% [45], 95\% [46]) and ii) they may represent less than $0.04 \%$ of building's total GWP. Furthermore, the embodied primary energy corresponding to the addition of glass doors would possibly represent less than $2 \%$ of the energy savings related [43]. There are other solutions to reduce refrigeration energy consumption, e.g., evaporative condenser, floating head pressure, suction pressure control, among others [25], but they are not included in the boundaries of the system. In a similar way, pipe network and other conditioning systems have been omitted.

Related to the lifespan, a report conducted on British supermarkets’ service life, resulted that the average age of supermarkets demolished studied was under 25 years old; some of them were just 15 years old and none of them had reached design buildings’ life span (50 years). In fact, from almost 600 existing, and still trading, supermarkets analysed, only a $2 \%$ were over 45 years old [47]. Still, this study considers reference building's service life optimization in accordance to design life span: 50 years. However, some products installed have a shorter expected lifespan, and consequently their replacement will be considered. In this sense, in general terms, it is assumed that facilities and installations have an expected service life of 20 years, while, most part of building materials may operate 50 years, except for some products, such as gypsum coating and windows, which have an expected service life of 25 years [48].

\subsection{Life Cycle Inventory (LCI) and quality data}

A food retail store building is a complex product composed by construction materials and fittings. The materials inventory is developed relying on European averages of the Ecoinvent v2.0 database (2007), one of the available databases, which best accomplishes expected features according to [49]. Specific fittings or components, that are not available in Ecoinvent v2.0 database (2007), are assessed relying on EN-15804-compilant Environmental Product Declarations (EPD) which include products' cradle to gate and, in some cases, cradle to grave 
impact divided into life cycle stages covered. With regard to refrigerant, in terms of GWP, direct emissions relative to $\mathrm{CO}_{2}$-eq for 100 years integration are based on "IPCC Fourth Assessment Report/IPCC07/ and Scientific Assessment/WMO10/” as contained in 2010 Report of the Refrigeration, Air Conditioning and Heat Pumps Technical Options Committee [50]. Furthermore, refrigerant manufacturing impacts refer to [51] in accordance with [50].

A comprehensive analysis on food retail stores average features has been performed relying on: i) the public 'Sustainable Development report' and 'Annual report' released by the main Spanish food traders, as well as, ii) national statistics, iii) existing regulation, iv) future market expectations and v) scientific bibliography on food retail stores. According to actual data consulted, it has been found that hypermarkets, in Spain, may have an average energy intensity between 350 [52] and $500 \mathrm{kWh} / \mathrm{m}^{2}$ year [15] whereas, supermarkets can amount about $610 \mathrm{kWh} / \mathrm{m}^{2}$ year [15].

\subsection{LCI Impact Assessment}

The impact categories evaluated in this study have been chosen in accordance with European 2020 targets, regarding energy consumption and environmental concerns. Thus, this study considers: i) Primary energy demand (MJ- eq), ii) Global Warming Potential (GWP) (kgCO ${ }_{2}-$ eq) and iii) Water demand (l). Primary energy demand is evaluated following Cumulative Energy Demand (CED) methodology v1.08 [53], which assesses demand related to production, use and disposal of a product, in this case the food retail store building. GWP indicator is calculated relying on IPCC v.1.02 characterisation factors with a time horizon consideration of 100 years [53]. For water demand throughout the complete life cycle, despite of the lack of methodology for desiccation potential integration into LCA, this study considers freshwater extractions (rivers, lakes, soils and wells) and excludes water used in turbines in hydraulic power production. Building components calculations of life cycle impacts have been conducted through the software tool SimaPro v7.3.2 [54]. It has to be highlighted that 
electricity mix emission factors used in this study, cover, besides energy generation direct emissions, other stages such as raw material acquisition, facilities manufacturing, transport, construction and dismantling [55]. In detail, for the reference building, Spanish electricity mix has been calculated in accordance to Ecoinvent v2.0 database (2007), corresponding to the year 2000.

\section{CASE STUDY DESCRIPTION}

European food retail accounted for almost $100,000 \mathrm{~km}^{2}$ of sales area by the year $2011,44 \%$ more than in 2000 [56]. These can be located in stand-alone buildings or business premises. According to Galvez-Martos, J.L., 2013, energy intensity $\left(\mathrm{kWh} / \mathrm{m}^{2}\right.$ year) is higher in smaller shops because bigger sales areas have lower refrigerated fittings density, 2 to $5 \mathrm{~m}$ and 6 to 12 m of display case per $100 \mathrm{~m}^{2}$ of sales areas in large supermarkets and small supermarkets, respectively [8], which are the most energy consuming items in food retail stores [57]. In addition, there can be defined three main refrigeration systems according to their configuration: i) stand-alone or plug-in systems, ii) condensing units and iii) centralized systems, which can be direct or indirect. In turn, food refrigeration fittings can be classified in terms of temperature provided: i) Medium Temperature (MT) and ii) Low Temperature (LT), which may have a length display cases ratio of 2:1 (MT: LT) [8]. There may be also variations on stores' energy consumption profile depending on services provided, such as, cafeteria, additional food preparation services, bakery and non-edible goods supply, among others. It has to be highlighted that all the processes involved in supermarket buildings are closely related to each other, e.g., lighting contributes to heat loads, refrigeration fittings density has consequences on heat recovery rates, just as, building's geometry and enclosures design, e.g., skylights affect Heating, Ventilation and Air Conditioning (HVAC) and lighting consumption. Furthermore, inappropriate or insufficient maintenance and cleaning works concerning refrigerant leakages can also entail rise on building’s energy consumption. 
The case study is based on a hypothetical building, located in Zaragoza (Spain) with a gross surface of $2,500 \mathrm{~m}^{2}$ and a sales area of $1,625 \mathrm{~m}^{2}$. It is assumed a sales area containing Medium Temperature (MT), multi-deck open shelves, with night curtains, and storage coolers connected to a centralized system, with a refrigerated fittings density of $5 \mathrm{~m}$ per $100 \mathrm{~m}^{2}$ [8] and refrigeration heat released to sales area of $-25 \mathrm{~W} / \mathrm{m}^{2}$. It must be noted that space thermal loads implications caused by refrigeration fittings may have significant variations regarding sales distribution, goods restocking and general thermostat location, among others. Standalone retail buildings are usually light-weighted with poor insulated enclosures. Traditionally, only roofs contain insulating materials. In addition, they hardly have any interior partitions, except for private areas. While a common dwelling may have a Partition surface: Gross surface rate of 1:1 [58], a relation 1:3 is considered for a food retail store, even though it has a greater height. Table 1 shows the main characteristics considered for the reference building, including the Seasonal Energy Efficiency Ratio (SEER) of the HVAC system.

Figure 3 displays the building's layout considered. The model has been defined considering habitual construction systems observed in current Spanish retail buildings and building regulation [59], (materials are detailed in Table 2), in order to evaluate environmental thermal loads related. In addition, it has been elaborated an occupation profile regarding current shopping habits and schedule perceived. Moreover, internal gains within, illumination and fittings are considered, including plausible programming for each type of space inside the food retail store. This is, the heat release caused by the illumination technology and electric devices, such as computers and cash registers (e.g., $5 \mathrm{~W} / \mathrm{m}^{2}$ in sales area and $12 \mathrm{~W} / \mathrm{m}^{2}$ in the office area), and refrigeration heat release previously mentioned (e.g., $-25 \mathrm{~W} / \mathrm{m}^{2}$ within sales area and $-5 \mathrm{~W} / \mathrm{m}^{2}$ in the warehouse).

The main LCI for Production, Construction and Use phases are specified in Table 2, Table 3, Table 4, respectively. The EOL inventory has been elaborated considering transport of solid 
waste products by $20-28$ tonnes-truck to the treatment plant located $26 \mathrm{~km}$ far from the building site. The main part of the materials is assumed to be landfilled, except for openings and metal items, which around $80-90 \%$ of their components may be separated and recycled.

\section{RESULTS}

Table 5 summarizes the LCA results obtained for the reference building, disaggregated by phases regarding CED, GWP and Water demand. Due to the high-energy intensity of food retail stores and the refrigerants typology used thus far, use phase accounts more than $90 \%$ of total impacts, as detailed in Table 5, but energy efficiency current practices will enlarge production phase significance. Furthermore, it must be highlighted that, consequently, the use phase results obtained for the reference building involve between 20-100 times Global Warming Potential of habitual building's LCA results. Figure 4 presents production phase breakdown for the reference building. Refrigerant manufacture, considering use phase refilling, may exceed roofing embodied carbon, while total refrigerant leakages may double electricity consumption's environmental impact during operational use phase. In fact, within use phase, refrigerant may stand for more than 60\% of GWP, whereas electricity consumption represents one third. The fact that, in terms of energy consumption, electricity is the main contributor to the food retail sector's buildings, is evidenced in the environmental impacts (mainly $\mathrm{CO}_{2}$ - eq), which are highly influenced by the supply mix's characterisation factor considered, in this case, $0.60 \mathrm{kgCO}_{2}$ - eq/kWh, from Ecoinvent v.2.0 for Spanish electricity mix. Consequently, given the importance of electricity as input and the dependency of its environmental impact to the supply mix, results are sensitive to the assumptions considered, e.g., from the same database, French characterisation factor may imply, in terms of GWP, less than half of the environmental impact related, mainly due to high contribution of nuclear power in this country. 


\subsection{Scenario assessment}

Even though the broad variability of stores attributes precludes the definition of a unique profile type, an approach to these types of buildings' performance has been developed in relation to the following main variables: geometry, construction systems, fittings technology and schedules. In this sense, improvement opportunities and prioritisation criteria can be evaluated in accordance with results. In addition, the scenarios proposed allow to estimate and/or evaluate potential variations on the results obtained.

Hence, in order to validate the methodology, as well as, evaluate the potential scatter of environmental implications, the study is articulated within three types of scenarios as summarized in Figure 5. From a static point of view, three improvement proposals are raised in line with EMAS criterion in order to evaluate improvement potential. Besides, in order to conduct a sensitivity analysis of the building typology selected, three scenarios compare: i) different location of the food retail store, ii) schedule and iii) different refrigerant options and management. Table 6 summarizes the variables considered for building typology sensitivity analysis. Beyond these scenarios, a dynamic approach is also proposed to evaluate prospective results accuracy and potential spatial and temporal variability. Due to the relevance of refrigerant and electricity in terms of GWP, sensitivity analysis at building and dynamic levels is conducted with regard to this impact category.

\subsubsection{Energy consumption optimization}

Commission Decision (EU) 2015/801 of 20 May 2015 defines a benchmark of excellence [6], that applied to the reference building would imply an averagely total consumption under 300 $\mathrm{kWh} / \mathrm{m}^{2}$ year. In order to build up decision support for the implementation of environmental management practices, three improvement proposals have been developed based on the reference building. The variables considered for the improvement proposals calculations are 
detailed in Table 7. They have been defined following a progressive improvement, regarding energy consumption and building materials choice, in order to achieve HVAC consumption excellence benchmark defined in Best Environmental Management Practices in Retail Trade Sector and halving operational energy consumption when reaching Proposal 3.

The results for the improvement proposals considered, in terms of Primary Energy Demand, Global Warming Potential and Water demand, are presented in Table 8 as the environmental net benefits of the subsequent scenarios, based on the methodology described by Dylewski et al., 2014 [60], translated to this specific case studies conditions; this is, the reduction of the impacts associated to the minimization of the energy demand taking into account the resulting environmental load in other stages e.g. product stage and transportation. These benefits are presented with regard to the reference building.

In terms of CED, the improvement achieved by the development of the scenarios proposed, can almost reach 50\%, in accordance with building's energy intensity reduction. In addition, the decrease of energy consumption can lead to almost $40 \%$ of water demand minimization without intervening on operational water demand. Nevertheless, GWP mitigation accomplished stands for $20 \%$ of reference building's environmental impact inasmuch as refrigerant charge and leakages represent more than $60 \%$ of this impact. Consequently, proposal 3 involves throughout the reference service life assessed around 3,500 MJ eq/m²year, implying less than $600 \mathrm{kgCO}_{2}-\mathrm{eq} / \mathrm{m}^{2}$ year of GWP and almost $10 \mathrm{~m}^{3} / \mathrm{m}^{2}$ year of water demand.

\subsubsection{Location of the store alternative}

Table 9, unlike Table 8, presents the results regarding GWP of a food retail store located in a premise integrated in a larger structure, instead of the potential benefits regarding the scenarios proposed for the reference stand-alone building presented in the latter. Towards 
LCA results for a supermarket located in a premise, it has been developed and fully modelled with Energy Plus engine a food retail store maintaining the same internal layout and adapting its enclosures and environmental conditions to a feasible situation of a commercial premise. It has been assumed a commercial place located on the ground floor of a block, remaining the central part of the supermarket's hood as the block's courtyard (with dimensions $40.0 \mathrm{x} 32.5$ meters). In addition, it has been considered to be located within the urban fabric with 20 meters street width delimiting two of its sides.

Measures regarding HVAC, such as façade insulation or heat recovery systems implemented in Proposals 2 and 3 may have minor consequences on total energy consumption, as shown in Table 9. Production phase result does not reveal significant changes in absolute terms, but the distribution of the impacts related to each building component does. On the one hand, external walls surface is reduced, as well as, the branding metal top of the walls avoided, while adiabatic walls surface is increased. On the other hand, aerated concrete slabs with acoustic insulation to separate the premise with upper spaces substitute part of the metal deck roofing. In terms of total LCA, the reference building located in a premise involves around $1 \%$ less of the impacts, while the benefits of energy efficiency strategies developed in the scenarios are gradually less effective and even involving greater impacts than stand-alone building when analysing scenario 3.

\subsubsection{Schedule alternative}

Opening hours is a tool that food retail companies use to differentiate themselves from competitors [61] and to attract additional demand when these are closed [62]. Thus, where there is deregulation of opening hours some retailers are extending their schedule. Due to perishable refrigerated goods require of continuous refrigeration, extended opening hours, may become a cost-effective decision in terms of energy consumption, when energyconsuming items are optimized through energy efficiency solutions. Results in terms of GWP 
for the scenarios related to opening $24 \mathrm{~h}$ a day-7 days a week are presented in Table 10. This variation, although extends opening hours, does not increase working hours regarding other services such as office work or food preparation. It should be noted that the energy consumption is not just a multiplying factor applied to the overall consumption. The energy consumption resulted from the simulation of the building has been adapted to the expected activity, schedule and fittings modifications. Spaces attached to sales area are assumed to become voided and their illumination and electric devices turned off after regular opening hours. In addition, commercial area occupation profile is adapted to the schedule, as well as, HVAC setting.

Analysing the results, regarding opening hours, the reference building could involve a $25 \%$ energy intensity increase and meet a GWP benefit of $0.1 \mathrm{kgCO}_{2^{-}} \mathrm{eq} / \mathrm{m}^{2}$ per opening hour. Applying energy efficiency measures within the scenarios assessed, GWP net benefit may almost duplicate.

\subsubsection{Refrigerant charge alternative}

Lately, the environmental impact regarding refrigerants has become a major issue, overcoming at times GWP associated to operational energy consumption. It can be constrainted: i) reducing refrigerant charge due to the refrigeration system configuration, e.g., decreasing refrigerant charge, from $\mathrm{R} 404 \mathrm{a} 4 \mathrm{~kg} / \mathrm{kW}$ in direct centralized systems to 0.4 kg/kW for indirect configurations with R404a/R744 [57] ; ii) minimizing leakage rates, e.g., annual (from 20\% to 15\%) and End-Of-Life (EOL) (from 15\% to 10\%), [17]; and iii) by the refrigerant choice - e.g. R404a involves 3,700 kgCO2- eq/kg, whereas R744 1 kgCO2- eq/kg [17]. According to HVAC\&R equipment suppliers [63], similar energy efficiency values to DX systems, running with R404a, can be achieved within R404a/R744 cascade layout. Consequently, this study's scenario only focuses on the refrigerant charge and not on energy 
consumption implications related. Table 11 presents the GWP results of three approaches suggested to reduce the environmental impact.

Developing a more exhaustive control over leakages, can lead to 10\% GWP minimization. Furthermore, the partial or total substitution of HFCs by environmental friendly refrigerants involve the reduction of more than half of total building's $\mathrm{CO}_{2}$ - eq emissions. Consequently, within use phase, electricity consumption becomes the main impacting issue, accounting more than $90 \%$ of the emissions. As a result, the combination of improvement proposal 3 and the refrigerant replacement achieves an $80 \%$ of GWP reduction throughout the complete building's life span.

\subsubsection{Dynamic assessment of relevant impact contributors}

Buildings’ long lifespan intensifies time-related variability [64]. These uncertainties and potential changes can be coped with a dynamic modelling approach [65]. Hence, in order to address potential running patterns and systems changes and/or spatial variability, a dynamic life cycle assessment is conducted in this study. DLCA approach is modelled from a double perspective, evaluating time-dependent and spatial variations regarding buildings' main environmental impact contributors (energy consumption and refrigerant leakages) figured in static LCA. For this purpose, beyond static LCA approach, [64] proposes a simplified mathematical model for temporal variations considering four parameter categories for buildings, namely: i) building operations, as for example, changes in energy consumption; ii) supply chain dynamics, such as, changes in efficiency of the electricity grid; iii) inventory dynamics, as the effect of environmental regulation on efficiency and emissions, among others, and iv) environmental system dynamics, like emission fates affected by changes in environment conditions. Supply chain functions have been accounted without time gap; this is, no time differences have been assumed between processes and emissions. In line with these parameters, the dynamic proposal in this paper considers: i) influence of refrigerant 
leakages on energy consumption, ii) electricity mix variation and iii) change on refrigerant choice.

Table 12 compiles, based on [64] DLCA parameters, the variables proposed for the scenario. Regarding DLCA parameters for buildings classified by [64], variations on building operations, supply chain dynamics and inventory dynamics are considered according to EU trends. Nevertheless, possible changes in background environmental systems are not taken into consideration, therefore characterization factors are not time-adjusted. Figure 6 represents variables and main causes related within building's life cycle. It has to be noted that future scenarios approach is always uncertain, due to: i) internal variables, such as actual operation, and ii) external variables, like the background [64]. However, these scenarios present sensitivity to future time-depending changes. Changes regarding site do not refer to building's displacement, but allow comparing environmental impacts differences between the same building with different electricity supply mix.

Within HVAC\&R systems, refrigerant leakages effects can be classified as direct and indirect impacts. Direct impacts refer to the consequence on climate change of the release of refrigerant substances to the atmosphere due to their Global Warming Potential. Indirect impact may have a double dimension. On the one hand, it refers to refrigerants embodied impacts, such as, manufacturing impacts [17]. On the other hand, it relates to systems' energy consumption [17]. Furthermore, undercharged systems may incur on electricity consumption rise and cooling capacity reduction [16]. Carbon Trust (2012) [25] estimates that energy consumption can escalate between $10 \%$ and $15 \%$ due to refrigerant-undercharged systems; less refrigerant flowing into the evaporator, reduces saturated evaporating temperature and so, efficiency. As an example, in a small system with no liquid receiver, electricity consumption increases by $2-4 \%$ as evaporation temperature drops of $1^{\circ} \mathrm{C}$ [16]. In addition, in some cases, system overcharging can become counterproductive too. Hence, annual refrigerant leakages 
cause energy consumption rise if not efficiently refilled. Several studies have previously been conducted to evaluate the impacts of refrigerant charge on heat pumps performance at smallscale systems, such as residential air conditioners as summarized in Table 13 [66], [67], [68], [69]. It has to be noted that $\mathrm{CO}_{2}$ systems are expected to be more sensitive to undercharged situations. In order to compare long term effects of not refilling of losses, static LCA, which considers energy consumption is not affected by leakages, is contrasted with every two years refilling works. This means, as reflected in Table 14 that the first year finishes with $80 \%$ of refrigerant charge and the following year at $60 \%$. No further undercharge is considered possible, in this case, due to cooling capacity required for perishable food conservation may not be achieved or compressor failure may occur. Energy consumption increase has been explored based on previous experiences and averages considering leakages as a continuous and successive process that affect energy efficiency progressively. Besides, the study does not cover potential energy consumption increase due to other materials and facilities deterioration or loss of performance.

On the other hand, electricity relevance among buildings' life cycle is sensitive to electricity generation mix. Significant differences can be found due to location. Furthermore, carbon intensity indicators are expected to be improved towards 2050 being averagely reduced by 80\% for EU-28 considering 2000 as base year and reaching 88\% in some countries like Spain [70]. Even so, from an LCA approach, electricity generation emission factor may double 2050 regular characterisation factors forecast. Figure 7 presents calculated LCA emission factors for electricity generation in accordance to expected gross electricity generation by source [71] and life cycle GHG emissions of each source expressed as $\mathrm{kgCO}_{2}$-eq per $\mathrm{kWh}$, as estimated by [55] and summarized by [72].

Additionally, EU aims to reduce by 60\% Fluorinated gases (F-gases) emissions by the year 2030 [24]. F-gas regulation will encourage the use of more environmental friendly 
refrigerants. As an example, as performed in Scenario 2 of the static analysis devoted to refrigerant substitution, $\mathrm{CO}_{2}$ will be considered involving higher energy consumption rise due to leakages.

DLCA results are presented in Table 15. Despite of dynamic approach considers energy consumption rise due to refrigerant leakages, long-term improvement on electricity mix reduces life cycle environmental impact calculations.

\subsubsection{Sensitivity analysis}

Food retail stores buildings' GWP present a wide variation of figures, as observed in Figure 8, from more than $800 \mathrm{kgCO}$-eq $/ \mathrm{m}^{2}$ year to less than $200 \mathrm{kgCO}$-eq $/ \mathrm{m}^{2}$ year. The improvement proposals can achieve a GWP reduction of about $150 \mathrm{kgCO}-\mathrm{eq} / \mathrm{m}^{2}$ year on the reference building and almost $200 \mathrm{kgCO}-\mathrm{eq} / \mathrm{m}^{2}$ year in the case of opening $24 \mathrm{~h}-7 \mathrm{~d}$ per week. From a static point of view, the major difference is observed on refrigerants choice.

It can be appreciated that electricity mix, from a spatial approach, has a significant relevance, accounting, in this case, for an environmental impact difference between Spanish and EU-28 average of about 10\% (Figure 9 ii). Introducing temporal dimension, the scenario compares Spanish electricity mix obtained from Ecoinvent v2.2 towards Spanish calculated LCA emission factor evolution unto 2050. Figure 9 iii and iv present results obtained. It can be observed the influence of energy efficiency loss due to inappropriate refill works, the influence of refrigerant and expected variations within electricity mix. If R404a is used, results differ about 20\% with regard to reference static LCA. Despite of energy consumption rise due to inadequate maintenance, electricity consumption environmental impact may be halved. If environmental friendly refrigerant is considered for complete building's life cycle, electricity consumption becomes the main contributor to environmental impact, representing more than $90 \%$ of total impact. Hence, energy efficiency loss due to refrigerant leakages may 
represent about $18 \%$ of total impacts, almost doubling energy consumption increase of DLCA with R404a. Furthermore, the difference between the static and dynamic approach of R744 case stands between 20 and 30\%.

\section{DISCUSSION AND CONCLUSIONS}

Food refrigeration has a significant role, both in terms of energy consumption and refrigerant emissions. Furthermore, the habitual lightness of stand-alone food retail buildings together with the high operational energy demand confers use phase the major part of the environmental impact. Nevertheless, they present noteworthy cost-effective improvement opportunities, underscoring thermal loads, fittings performance and refrigerant choice. However, due to long lifespan of buildings and desired future changes on electricity generation, DLCA approach reveals significant changes on figures obtained, reaching a difference between $15-30 \%$ of final environmental impact. As electricity weight is increased with regard to total environmental impact, more sensitiveness to electricity consumption and/or generation mix variations is expected. Furthermore, the role of energy managers and energy management systems becomes relevant in order to optimize energy efficiency strategies and/or obtain real-time impact assessment data.

According to static results obtained, combining the use of environmental friendly refrigerants, together with energy efficiency measures regarding lighting and HVAC\&R systems there can be achieved environmental impact savings of $80 \%$. Moreover, heat recovery systems, can sometimes meet total heating demands or even recover excess heat, enabling to sell the extra heat in a city district network. Regarding opening hours, extension of commercial schedule may lead to better exploitation of energy consumption, due to the habitual main energyconsuming system in a food retail store, refrigeration fittings, requires continued power supply. However, it should be noted, that in terms of economic and social impact of 
commercial schedule, other variables may be taken into account, such as night shift implications.

Analysing dynamic approach, when high-GWP refrigerants are used, electricity consumption and so, energy efficiency strategies, loose their relevance towards refrigerant leakages impact. In fact, it moves from a estimated Electricity:Refrigerant impact rate of 2:3 to 2:4.6 rate. However, when low-GWP refrigerants operate, specifically $\mathrm{CO}_{2}$ whose leakages involve higher loss of performance, electricity consumption becomes the main contributor to environmental impact.

Then, it can be concluded, that non-residential buildings, and particularly food retail stores buildings, demand a LCA temporal and spatial dynamic apporach. The fact that electricity and refrigerant emissions involve most part of these building typology's environmental impacts in terms of $\mathrm{CO}_{2}$-eq together with its sensitiveness to spatial and/or temporal variations, illustrates the relevance of taking into consideration potential future scenarios regarding electricity mix improvement, energy consumption increase due to refrigerant undercharge conditions and refrigerant substitution. In addition, as refrigerant emissions are reduced due to F-gas regulation, energy consumption acquires a mayor role. Hence, the methodological approach proposed results suitable for non-residential buildings environmental evaluation and, furthermore, it is able to gauge environmental implications of the particular case of food retail stores buildings.

Future research may be conducted on different refrigeration systems configuration and other non-residential buildings typologies, such as offices. Also, temporal variations with regard to climate change characterization factors or energy costs may be considered. In addition, towards sustainability assessment, environmental impact results should be aggregated to economic and social dimensions evaluation in order to obtain a holistic approach. Certainly, on the road to sustainability, a structured a comparable system is required, taking into account 
stakeholders' perception and form of interaction within the building from environmental, social and economic point of view, and including building management issues.

\section{ACKNOWLEDGMENTS}

This contribution has been developed in the framework of the SuperSmart project'Expertise hub for a market uptake of energy-efficient supermarkets by awareness raising, knowledge transfer and pre-preparation of an EU Ecolabel', funded by the EU under the H2020 Innovation Framework Programme, project number 696076.

\section{REFERENCES}

[1] European Commission. EU Buildings Database. https://ec.europa.eu/energy/en/eubuildings-database2018.

[2] Eurostat. Energy balance flow for European Union (28 countries). http://ec.europa.eu/eurostat/cache/sankey/sankey.html?geos=EU28\&year=2016\&unit=KTOE \&fuels $=0000$ \&highlight $=$ \&nodeDisagg $=1111111111 \&$ flowDisagg $=$ false \&translateX $=-$ 1634\&translateY=-26\&scale=1\&language=EN, 2016.

[3] European Commission. Energy modelling. Energy efficiency. Energy intensity indicators. https://ec.europa.eu/energy/en/content/energy-modelling-interactivegraphs?type=msline\&themes=s_51_tertiary-energy-on-value-added2018.

[4] Instituto para la Diversificacion y Ahorro de la Energía (IDAE). Informe Anual de Consumos Energéticos. $7^{\circ}$ Edición. Secretaria General. Departamento de Planificación y Estudios. : Ministerio de Industria, Energía y Turismo. Gobierno de España; 2016.

[5] EC (European Commission). Regulation (EC) No 1221/2009 of the European Parliament and of the Council of 25 November 2009 on the Voluntary Participation by Organisations in a Community Eco-management and Audit Scheme (EMAS), Repealing egulation (EC) No 761/2001 and Commission Decisions 2001/681/EC and 2006/193/EC. In: Official Journal of the European Union, editor. L 342/1. Brussels2009.

[6] EC (European Commission). COMMISSION DECISION (EU) 2015/801 of 20 May 2015 on reference document on best environmental management practice, sector environmental performance indicators and benchmarks of excellence for the retail trade sector under Regulation (EC) No 1221/2009 of the European Parliament and of the Council on the voluntary participation by organisations in a Community eco-management and audit scheme (EMAS) (notified under document C(2015) 3234). In: Official Journal of the European Union, editor. L 127/25,. Brussels2015.

[7] Cortella G, D'Agaro P. Chapter 10: integration of air conditioning, refrigeration and energy generation in supermarkets. In: J.A. Evans A.M. Foster John Wiley \& Sons Chichester, editor. Sustainable Retail Refrigeration. UK2016. 
[8] Galvez-Martos J-L, Styles D, Schoenberger H. Identified best environmental management practices to improve the energy performance of the retail trade sector in Europe. Energy Policy. 2013;63:982-94.

[9] Mercadona. Memoria Medio Ambiente 2011-2012. https://info.mercadona.es/document/es/memoria-medioambiental-20112012.pdf, Valencia, 2012.

[10] MINES Paris- Tech. Open Refrigerant Inventories and Emissions (RIEP). 2014.

[11] ANSI/ASHRAE. Standard 34-2013. Designation and Safety Classification of Refrigerants. USA: Safety Group Classifications 2013.

[12] Iowa State University's Center for Industrial Research and Service. Chapter 8: Refrigeration. Energy-Related Best practices: A sourcebook for the food industry http://www.ciras.iastate.edu/publications/EnergyBP-FoodIndustry/, 2005.

[13] Harby K. Hydrocarbons and their mixtures as alternatives to environmental unfriendly halogenated refrigerants: An updated overview. Renewable and Sustainable Energy Reviews. 2017;73:1247-64.

[14] Shecco. Natural Refrigerants: Global market trends. Tokyo2017.

[15] AUCHAN RETAIL ESPAÑA. Informe de actividad y responsabilidad social corporativa. El emprendedor de hoy las nuevas experiencias de auchan retail. Auchan Retail España ed2015.

[16] Koronaki IP, Cowan D, Maidment G, Beerman K, Schreurs M, Kaar K, et al. Refrigerant emissions and leakage prevention across Europe - Results from the RealSkillsEurope project. Energy. 2012;45:71-80.

[17] International Institute of Refrigeration. Life Cycle Climate Performance Working Group. Guideline for Life Cycle Climate Performance v.1.2. 2016.

[18] Ozone Secretariat. United Nations Environment Programme. Handbook for the Montreal Protocol on Substances that Deplete the Ozone Layer. 2016.

[19] EC (European Commission). DIRECTIVE 2012/27/EU OF THE EUROPEAN PARLIAMENT AND OF THE COUNCIL of 25 October 2012 on energy efficiency, amending Directives 2009/125/EC and 2010/30/EU and repealing Directives 2004/8/EC and 2006/32/EC. In: Official Journal of the European Union, editor. L 315/1. Brussels2012.

[20] EC (European Commission). Report from the Commission to the European Parliament, the Council, the European Economic and Social Comittee and the Committe of the regions on the implementation of the Circular Economy Action Plan. COM(2017) 33 final. Brussels2017.

[21] EC (European Commission). REGULATION (EU) No 517/2014 OF THE EUROPEAN PARLIAMENT AND OF THE COUNCIL of 16 April 2014 on fluorinated greenhouse gases and repealing Regulation (EC) No 842/2006. In: Official Journal of the European Union, editor. L 150/195. Brussels2009.

[22] Browne AW, Harris PJC, Hofny-Collins AH, Pasiecznik N, Wallace RR. Organic production and ethical trade: definition, practice and links. Food Policy. 2000;25:69-89.

[23] United Nations. Pacto Mundial. Red Española. http://www.pactomundial.org/nuestossocios/.

[24] Mercadona. Informe Pacto Mundial. Valencia2016. 
[25] Carbon Trust. Refrigeration Road Map. UK2012.

[26] BREEAM. https://www.breeam.com/case-studies/retail/131-vaxjo-sweden/, 2017.

[27] US Green Building Council. LEED v4 for BUILDING DESIGN AND CONSTRUCTION.

https://www.usgbc.org/sites/default/files/LEED\%20v4\%20BDC_04.6.18_current.pdf,

Updated, April 2018.

[28] Target Zero Programme. Guidance on the design and construction of sustainable, low carbon supermarket buildings. 2011.

[29] Braun MR, Altan H, Beck SBM. Using regression analysis to predict the future energy consumption of a supermarket in the UK. Applied Energy. 2014;130:305-13.

[30] Spyrou MS, Shanks K, Cook MJ, Pitcher J, Lee R. An empirical study of electricity and gas demand drivers in large food retail buildings of a national organisation. Energy and Buildings. 2014;68, Part A:172-82.

[31] International Organisation for Standardisation. ISO 14040:2006, Environmental Management - Life Cycle Assessment - Principles and Framework. International Organization for Standardization. Geneva, Switzerland 2006.

[32] International Organisation for Standardisation. ISO 14044:2006, Environmental Management - Life Cycle Assessment - Requirements and guidelines. International Organization for Standardization. Geneva, Switzerland 2006.

[33] European Committee for Standardization. CSN EN 15643-1: Sustainability of construction works - Sustainability assessment of buildings - Part 1: General framework. 2010.

[34] European Committee for Standardization. CSN EN 15643-2: Sustainability of construction works - Assessment of buildings - Part 2: Framework for the assessment of environmental performance. 2011.

[35] European Committee for Standardization. CSN EN 15643-3: Sustainability of construction works - Assessment of buildings - Part 3: Framework for the assessment of social performance. 2012.

[36] European Committee for Standardization. CSN EN 15643-4: Sustainability of construction works - Assessment of building - Part 4: Framework for the assessment of economic performance. 2012.

[37] European Committee for Standardization. EN 15804:2012+A1: 2013 Sustainability of Construction Works - Environmental Product Declarations - Core Rules for the Product Category of Construction Products2013.

[38] European Committee for Standardization. CSN EN 15978: Sustainability of construction works - Assessment of environmental performance of buildings - Calculation method. 2011.

[39] Design Builder Software Limited. Design Builder Program Help V4.7. https://www.designbuilder.co.uk/helpv4.7/, 2016.

[40] U.S. Department of Energy. Input Output Reference. EnergyPlus Version 8.9.0 Documentation.

https://energyplus.net/sites/all/modules/custom/nrel_custom/pdfs/pdfs_v8.9.0/InputOutputRef erence.pdf, 2018. 
[41] Cecchinato L, Corradi M, Minetto S. Energy performance of supermarket refrigeration and air conditioning integrated systems working with natural refrigerants. Applied Thermal Engineering. 2012;48:378-91.

[42] R. Faramzi. Investigation of Air Curtains in open refrigerated display cases- Project overview. PAC Meeting2007.

[43] Evans J. Are Doors on Fridges the Best Environmental Solution for the Retail Sector? Institute of Refrigeration at London Chamber of Commerce and Industry. 2014.

[44] D. Bibalou DA, G. Maidment and I. Chaer,. Life Cycle Assessment and product carbon footprint of refrigeration systems. 10th IIR Gustav Lorentzen Conference. Delft2012.

[45] D. Bibalou IC, D. Andrews, G. Maidment and M. Longhurst,. A carbon footprint study of a remanufactured and/or refurbished retail refrigerated display cabinet. Congrés International surl'Analyse du Cycle de Vie. Lille2011.

[46] Watkins R, Tassou S. Life cycle analysis of the environmental impact of different cabinet designs. 2006:701.

[47] Richardson S, Hyde, K., Connaughton, J. ,Merefield, D. ,. Service life of UK supermarkets: origins of assumptions and their impact on embodied carbon estimates. World Sustainable Building. Barcelona2014.

[48] National Association of Home Builders/ Bank of America Home Equity. Study of life expectancy of home components. https://www.interstatebrick.com/sites/default/files/library/nahb20study20of20life20expectanc y20of20home20components.pdf2007.

[49] Martínez-Rocamora A, Solís-Guzmán J, Marrero M. LCA databases focused on construction materials: A review. Renewable and Sustainable Energy Reviews. 2016;58:56573.

[50] UNEP. 2010 REPORT OF THE REFRIGERATION, AIR CONDITIONING AND HEAT PUMPS TECHNICAL OPTIONS COMMITTEE. 2011.

[51] Johnson EP. Air-source heat pump carbon footprints: HFC impacts and comparison to other heat sources. Energy Policy. 2011;39:1369-81.

[52] Centros comerciales Carrefour SA. Informes de Actividad y Compromiso e Informes de Desarrollo Sostenible, 2007-2015.

[53] Frischknecht R. JN, Althaus H.-J., Bauer C.: Doka G., Dones R., Hischier R., Hellweg S., Humbert S., Köllner T., Loerincik Y., Margni M., Nemecek T.,. Implementation of Life Cycle Impact Assessment Methods. ecoinvent report No. 3, v2.0. Swiss Centre for Life Cycle Inventories. Dübendorf, 2007.

[54] PRé Sustainability. SimaPro Database Manual. Methods Library. https://www.presustainability.com/download/manuals/DatabaseManualMethods.pdf, 2018.

[55] World Energy Council. Comparison of Energy Systems Using Life Cycle Assessment. A Special Report of the World Energy Council. 2004.

[56] European Union. The economic impact of modern retail on choice and innovation in the EU food sector. In: International ECELA, editor. Luxembourg: Publications Office of the European Union, 20142014.

[57] Tassou SA, Ge Y, Hadawey A, Marriott D. Energy consumption and conservation in food retailing. Applied Thermal Engineering. 2011;31:147-56. 
[58] Martín Gutiérrez E, Estévez Cimadevila J. Estimación de la sobrecarga de tabiquería en estructuras de edificación residencial. 2004. 2004;55:13.

[59] Ministerio de vivienda. Gobierno de España. Real Decreto 134/2006, de 17 de Marzo, por el que se aprueba el Código Técnico de la Edificación. 2006.

[60] Dylewski R, Adamczyk J. 12 - Life cycle assessment (LCA) of building thermal insulation materials. Eco-efficient Construction and Building Materials: Woodhead Publishing; 2014. p. 267-86.

[61] Rouwendal J, Rietveld P. An economic analysis of opening hours for shops. Journal of Retailing and Consumer Services. 1998;5:119-28.

[62] Inderst R, Irmen A. Shopping hours and price competition. European Economic Review. 2005;49:1105-24.

[63] Danfoss S.A. Alternativas en Sistemas de Refrigeración con CO2 para Distribución Alimentaria. 2015.

[64] Collinge WO, Landis AE, Jones AK, Schaefer LA, Bilec MM. Dynamic life cycle assessment: framework and application to an institutional building. The International Journal of Life Cycle Assessment. 2013;18:538-52.

[65] Anand CK, Amor B. Recent developments, future challenges and new research directions in LCA of buildings: A critical review. Renewable and Sustainable Energy Reviews. 2017;67:408-16.

[66] Kim W, Braun JE. Evaluation of the impacts of refrigerant charge on air conditioner and heat pump performance. International Journal of Refrigeration. 2012;35:1805-14.

[67] Grace IN, Datta D, Tassou SA. Sensitivity of refrigeration system performance to charge levels and parameters for on-line leak detection. Applied Thermal Engineering. 2005;25:55766.

[68] Kim DH, Park HS, Kim MS. The effect of the refrigerant charge amount on single and cascade cycle heat pump systems. International Journal of Refrigeration. 2014;40:254-68.

[69] Cho H, Ryu C, Kim Y, Kim HY. Effects of refrigerant charge amount on the performance of a transcritical $\mathrm{CO} 2$ heat pump. International Journal of Refrigeration. 2005;28:1266-73.

[70] European Commission. Energy modelling. Decarbonisation_Carbon intensity indicators. Electricity and steam production. https://ec.europa.eu/energy/en/content/energy-modellinginteractive-graphs?type $=$ msline\&themes $=$ s 70 electricity-and-steam-production2018.

[71] European Commission. Energy modelling. Electricity_ Gross electricity generation by source. $\quad$ https://ec.europa.eu/energy/en/content/energy-modelling-interactivegraphs?type=msline\&themes=s_70_electricity-and-steam-production, 2018.

[72] Wilson L. Shrink your housing footprint. Shrink that footprint. http://shrinkthatfootprint.com/shrink-your-housing-footprint., 2018. 


\section{TABLE CAPTION}

Table 1. Reference building data

Table 2. Production phase main LCI

Table 3. Construction phase main LCI

Table 4. Use phase main LCI

Table 5. LCA results for the reference building

Table 6. Variations proposed

Table 7. Scenarios considered

Table 8. Environmental net benefits of the scenarios proposed

Table 9. Variations proposed

Table 10. LCA results for supermarket located in a premise $\left(\mathrm{kgCO}_{2}-\mathrm{eq} / \mathrm{m}^{2} \mathrm{year}\right)$

Table 11. LCA results for supermarket with refrigerant modifications. ( $\left.\mathrm{kgCO}_{2}-\mathrm{eq} / \mathrm{m}^{2} \mathrm{year}\right) \mathrm{i}$ ) indirect system. (R404a charge: $0.4 \mathrm{~kg} / \mathrm{kW}$; R744 charge: $4.0 \mathrm{~kg} / \mathrm{kW}$ ); ii) Leakages minimization (ALR=15\%; EOL=10\%); iii) Refrigerant substitution. R744 charge: 4.0 kg/kW

Table 12. DLCA selected variables

Table 13. Review of energy consumption rise due to refrigerant leakages

Table 14. Refrigerant undercharge assumptions

Table 15. DLCA results ( $\left.\mathrm{kgCO}_{2}-\mathrm{eq} / \mathrm{m}^{2} \mathrm{year}\right)$

\section{FIGURE CAPTION}

Figure 1. LCA methodology proposed

Figure 2. Externalities and variables affecting building's performance 
Figure 3. Reference building layout

Figure 4. Reference building's production phase breakdown

Figure 5. Scenarios evaluated

Figure 6. Spatial and time dependent variables considered in building operation

Figure 7. Electricity generation LCA emission factors expected evolution. (EU28 EF LCA:

EU-28 Life Cycle electricity emission factor; ES EF LCA: Spanish Life Cycle electricity emission factor)

Figure 8. Static sensitivity analysis

Figure 9. Dynamic sensitivity analysis 


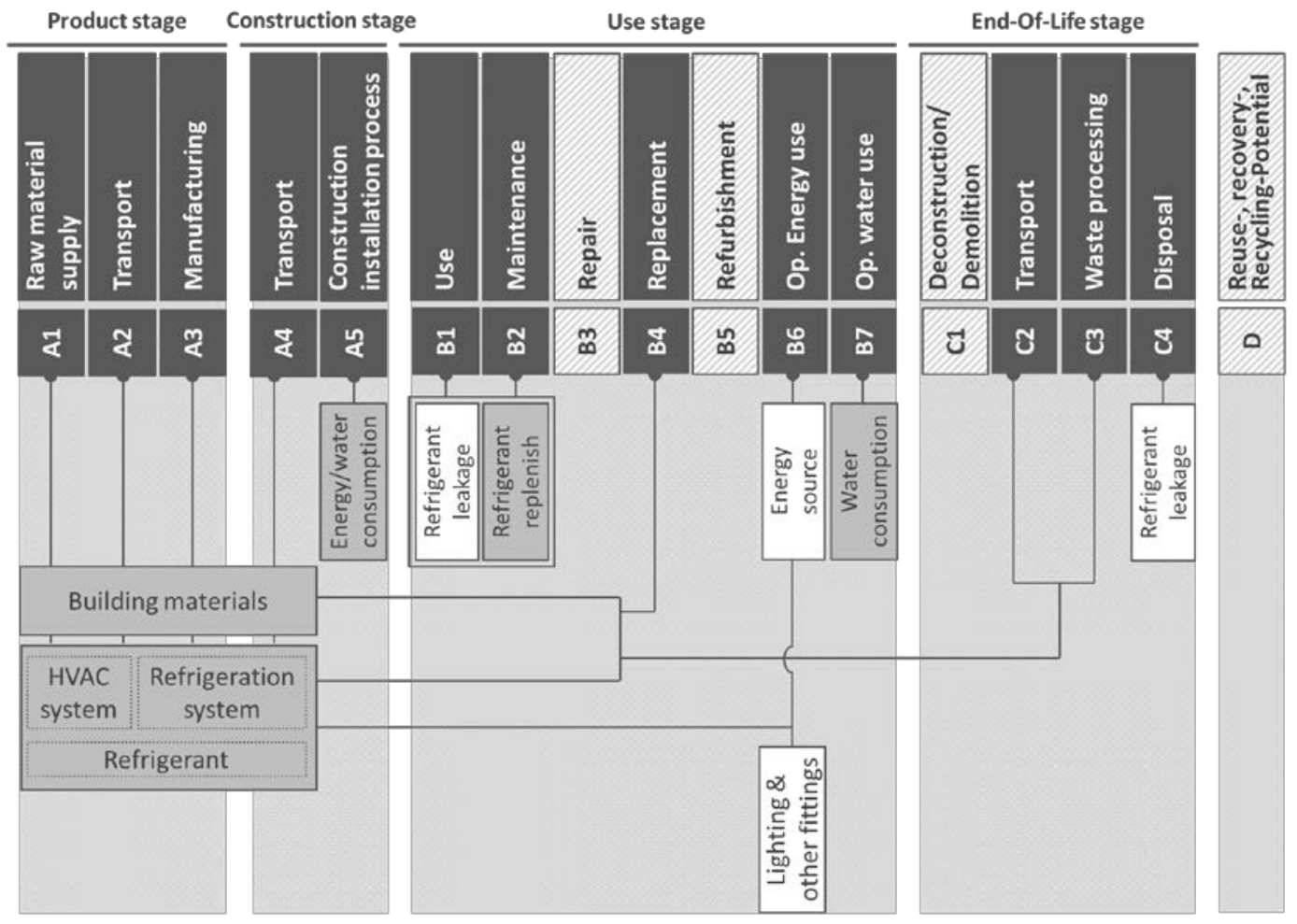

Figure 1. LCA methodology proposed 


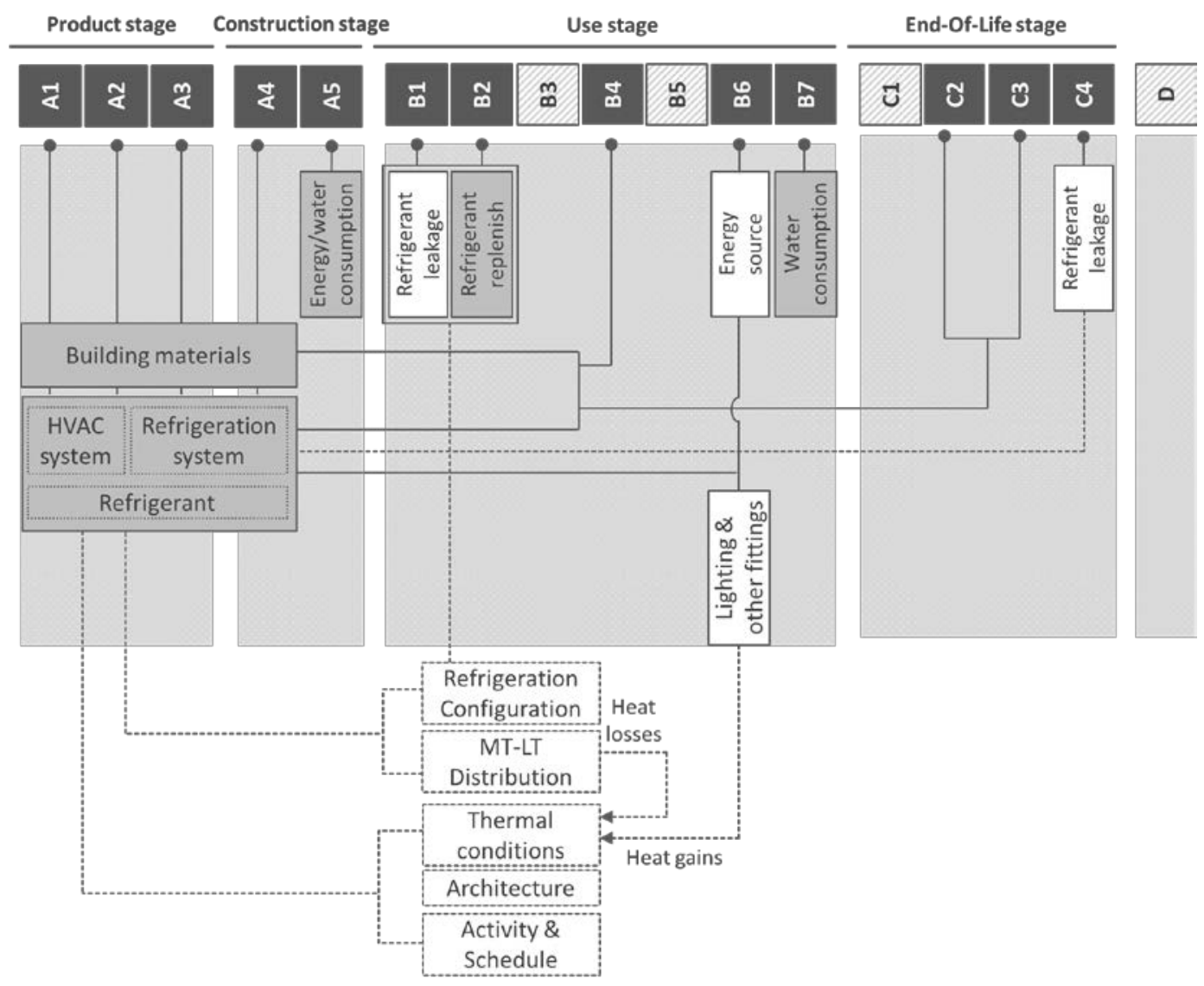

Figure 2. Externalities and variables affecting building's performance 


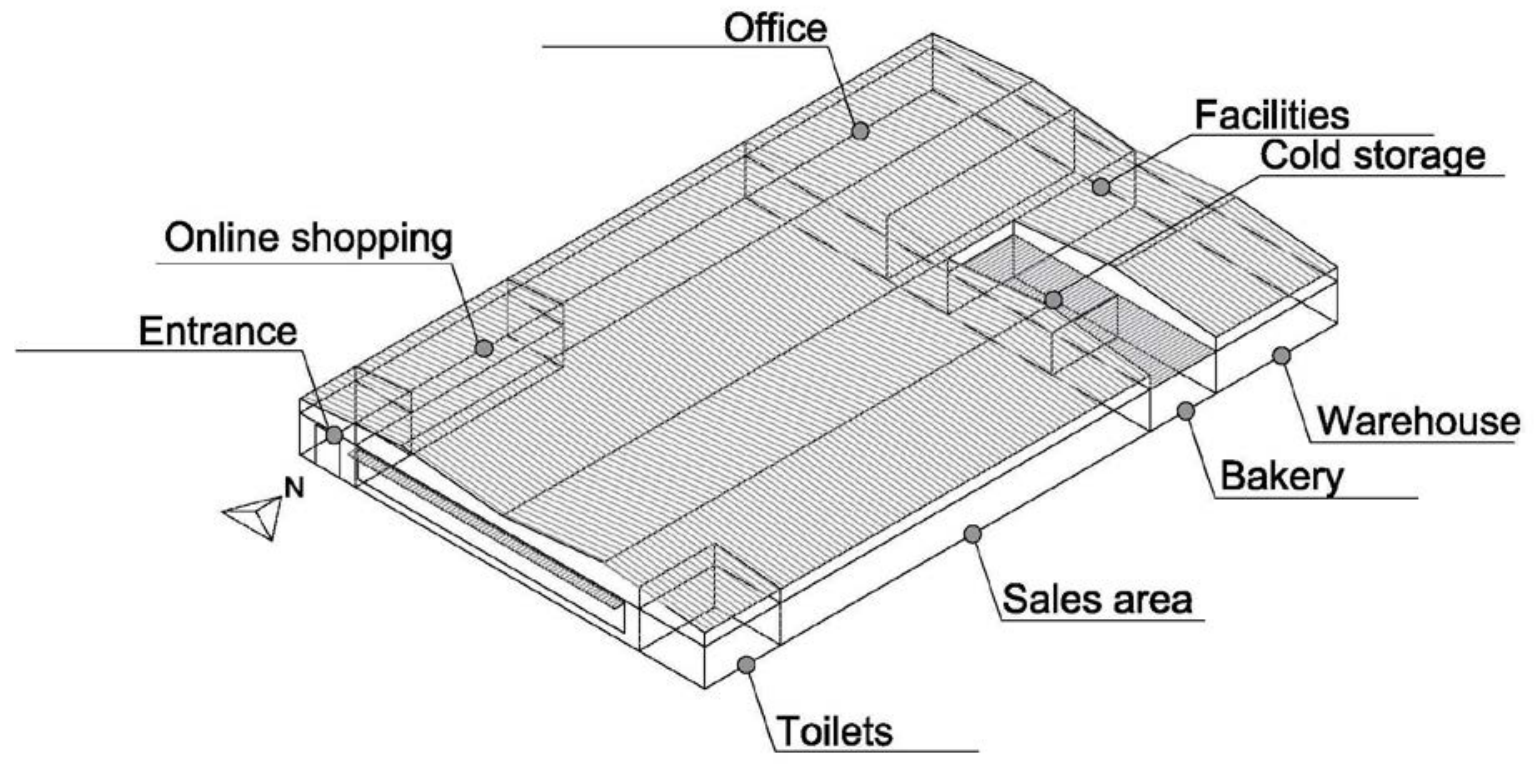

Figure 3. Reference building layout 


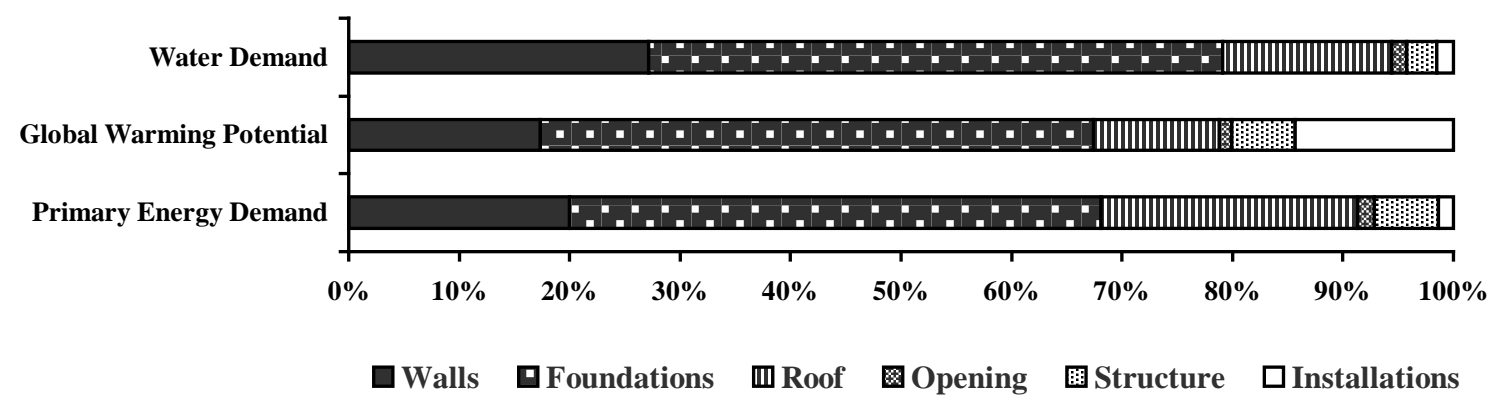

Figure 4. Reference building's production phase breakdown 


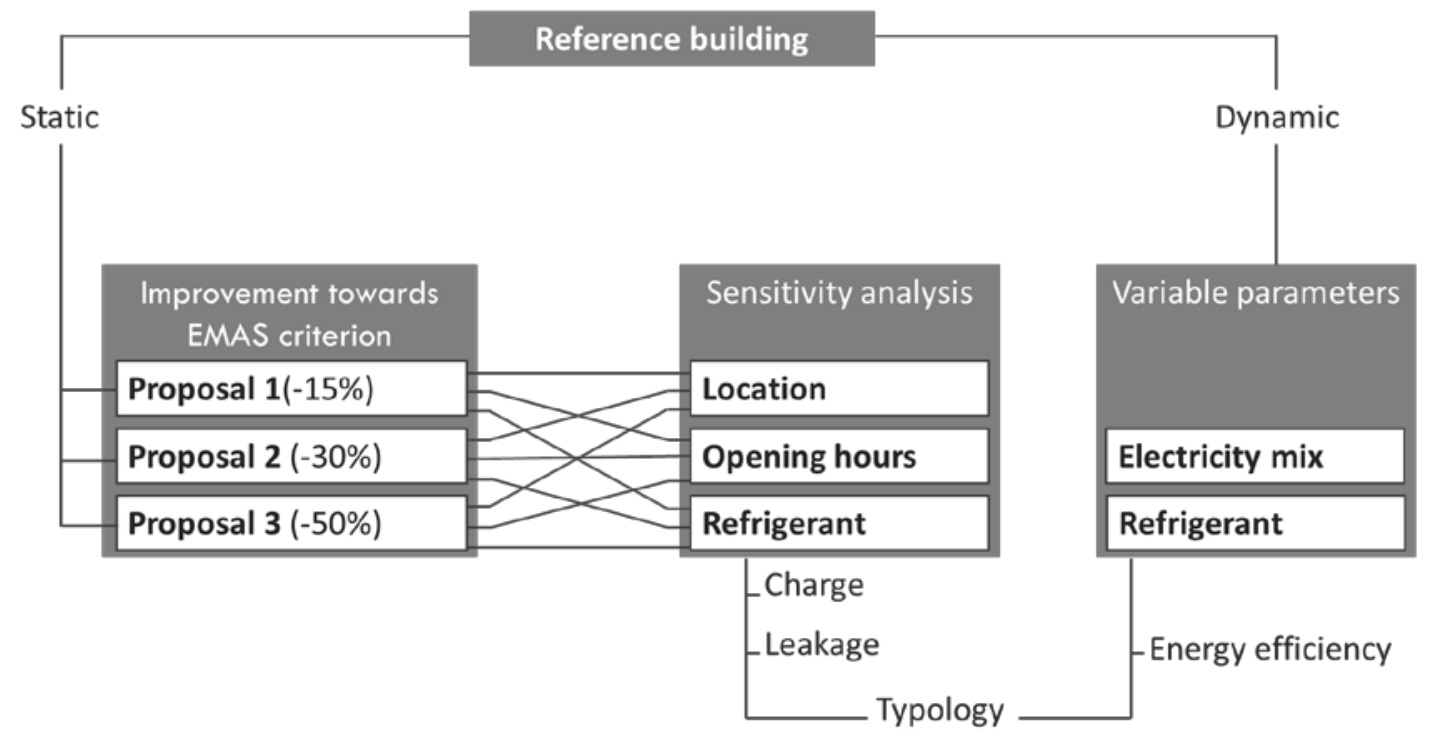

Figure 5. Scenarios evaluated 


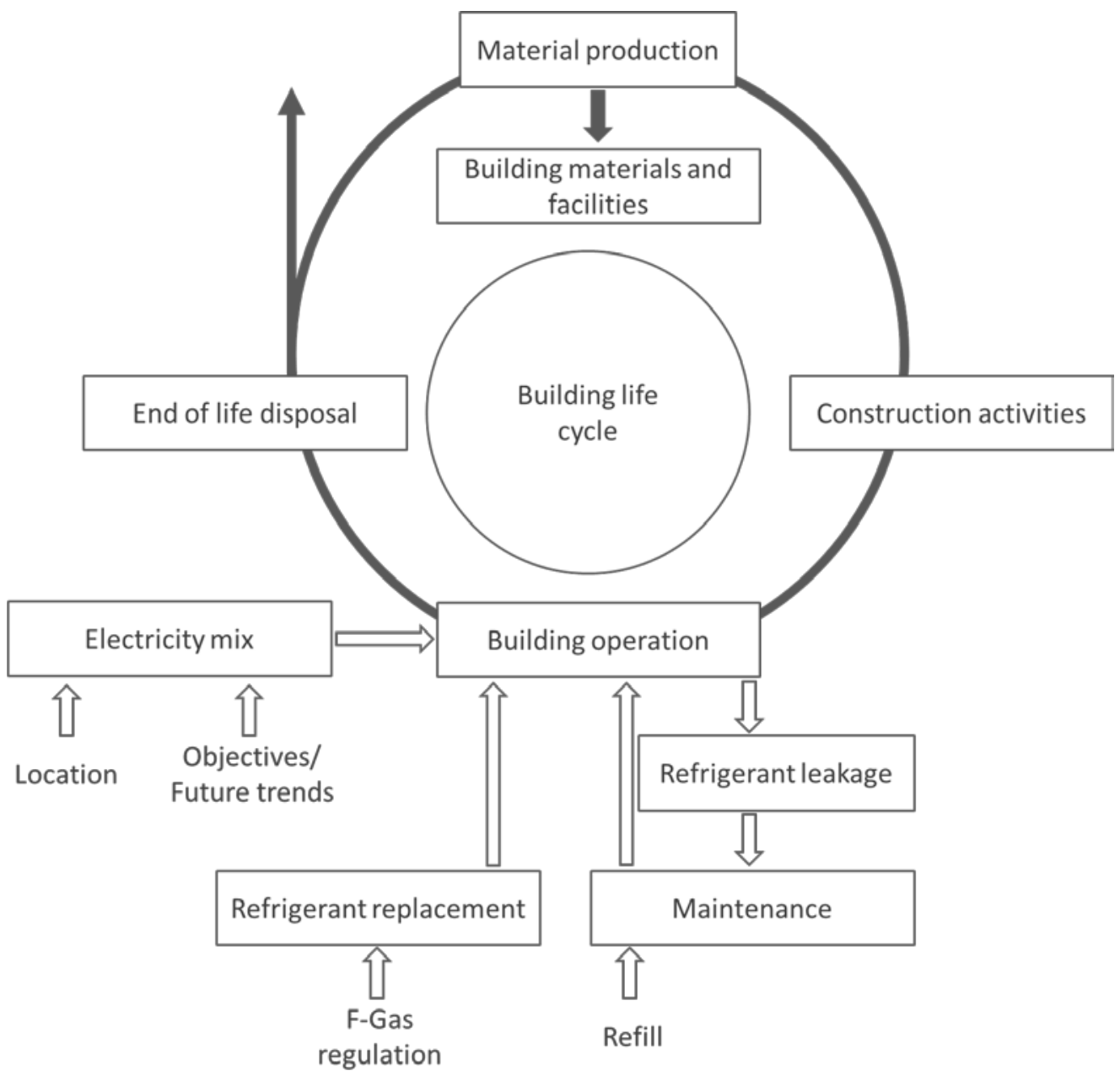

Figure 6. Spatial and time dependent variables considered in building operation 


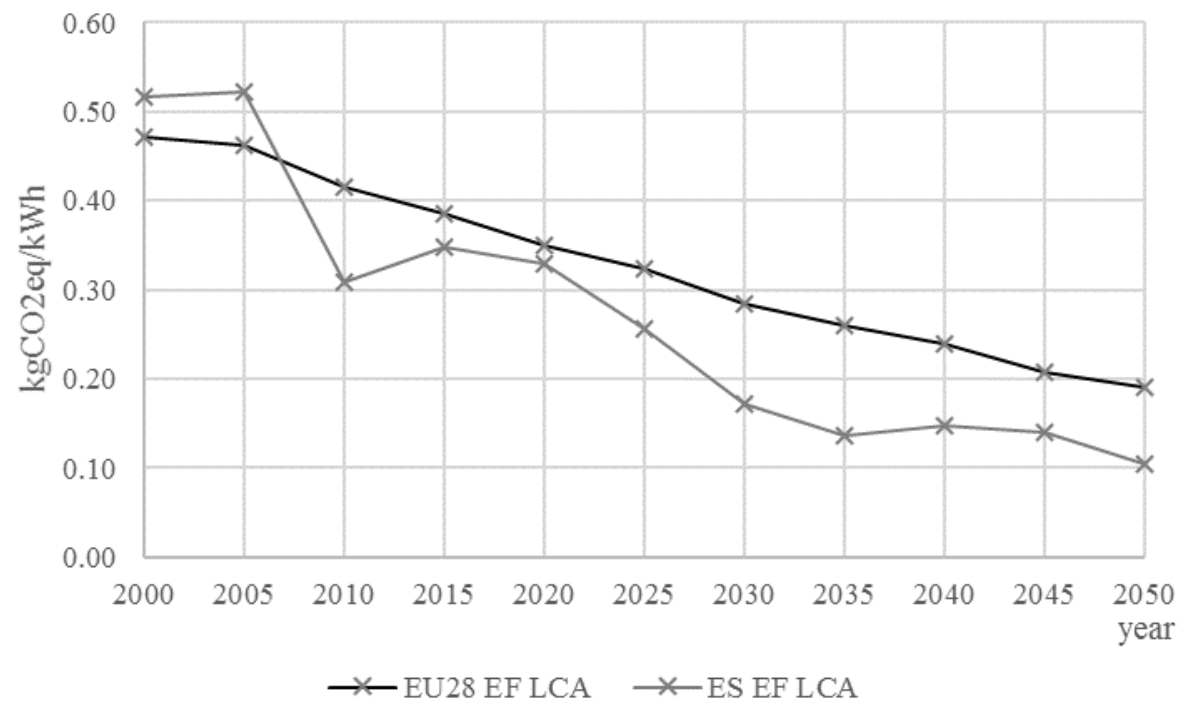

Figure 7. Electricity generationLCA emission factors expected evolution. (EU28 EF LCA: EU-28 Life Cycle electricity emission factor; ES EF LCA: Spanish Life Cycle electricity emission factor) 


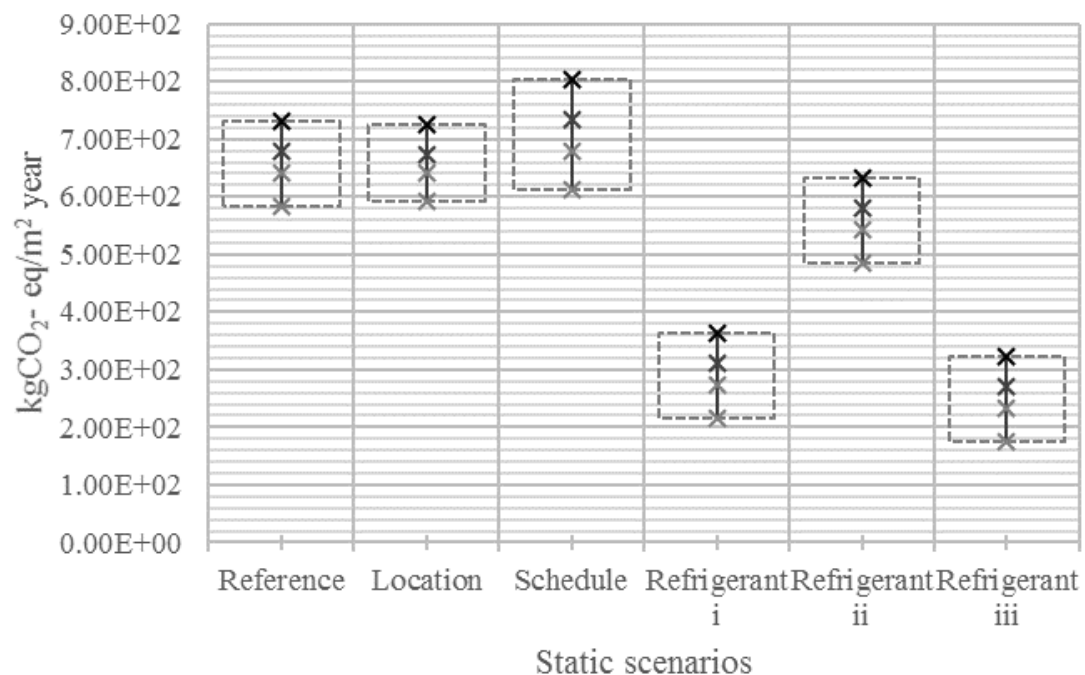

Imprevement proposals: $\times$ Base $\times \mathrm{P} 1 \times \mathrm{P} 2 \times \mathrm{P} 3$

Figure 8. Static sensitivity analysis 


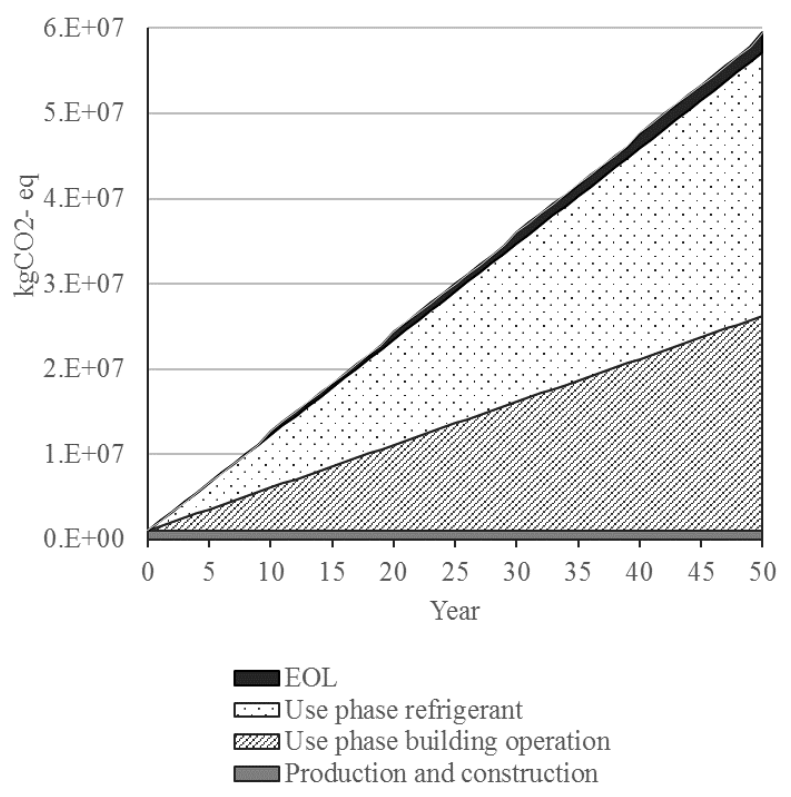

i) Cumulative static LCA Reference (ES-Ecoinvent v2.2 electricity mix)

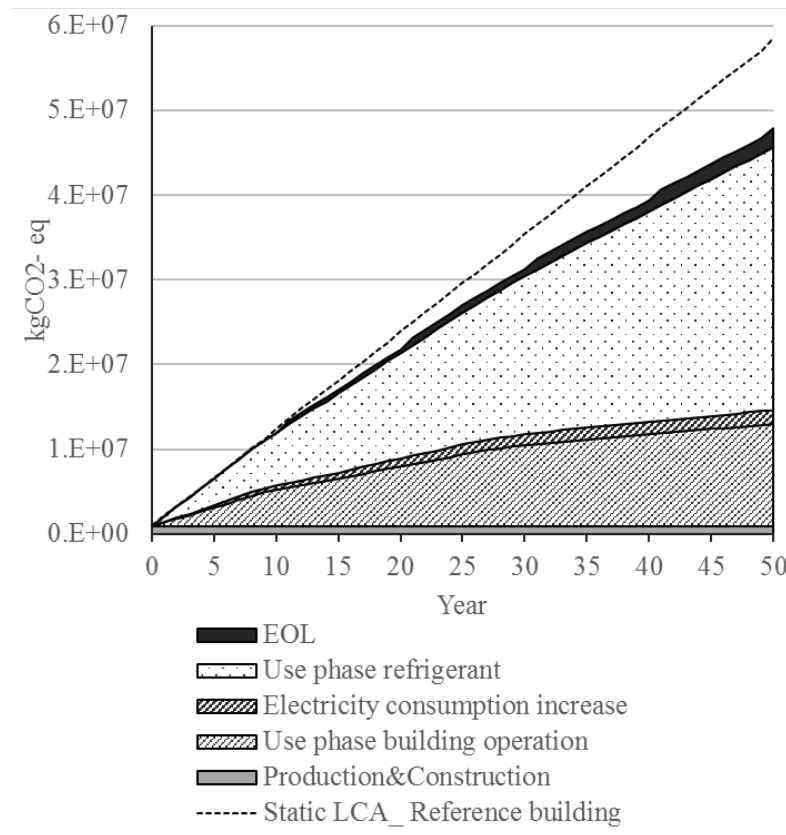

iii) Cumulative dynamic LCA results

(ES electricity mix trend, energy efficiency loss due to(ES electricity mix trend, energy efficiency loss due to leakages, R404a)

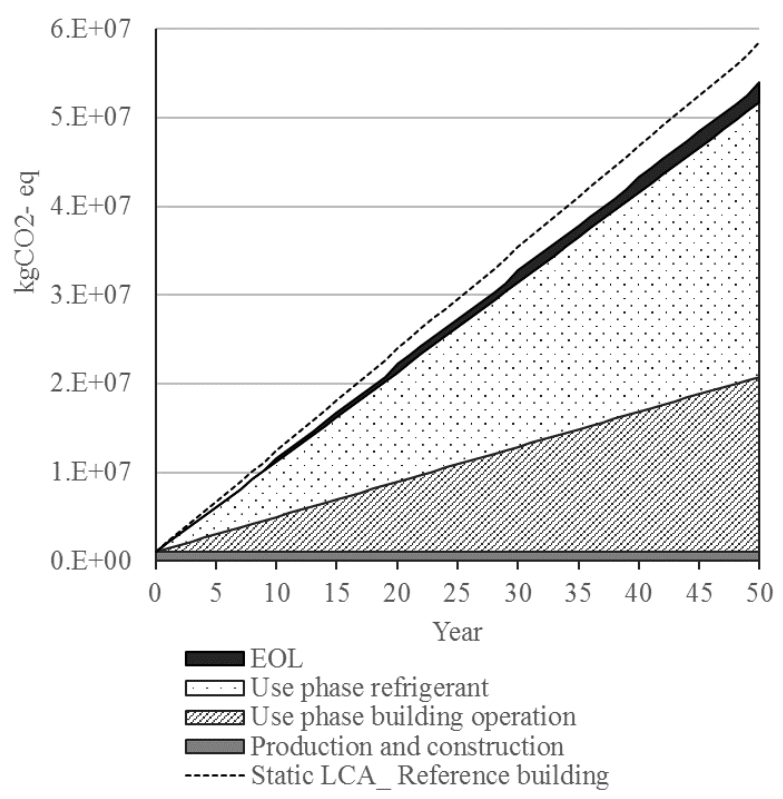

ii) Cumulative time-static LCA results (Spatial variation: EU LCA electricity mix)

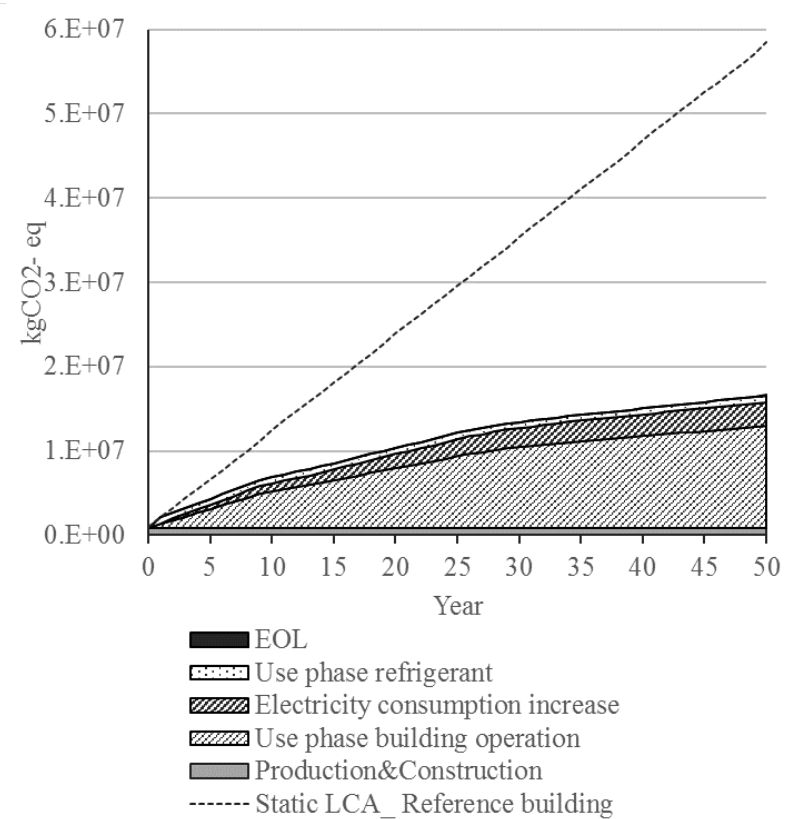

iv) Cumulative dynamic LCA results

leakages, $\mathrm{CO}_{2}$ )

Figure 9. Dynamic sensitivity analysis 
Table 1. Reference building data

\begin{tabular}{ccc}
\hline Characteristic & Value & Units \\
\hline Façades E-W & 875 & $\mathrm{~m}^{2}$ \\
Façades N-S & 560 & $\mathrm{~m}^{2}$ \\
Indoor height & 3.50 & $\mathrm{~m}$ \\
Max. gable height & 5.80 & $\mathrm{~m}$ \\
Glazing & $<10$ & $\%$ \\
Main roofing typology & Pitched roof & - \\
External wall average U-value & 1.89 & $\mathrm{~W} / \mathrm{m}^{2} \mathrm{~K}$ \\
Roof average U-value & 0.33 & $\mathrm{~W} / \mathrm{m}^{2} \mathrm{~K}$ \\
Glazing U-value & 3.10 & $\mathrm{~W} / \mathrm{m}^{2} \mathrm{~K}$ \\
Air tightness & 0.70 & $\mathrm{arch}$ \\
Opening schedule & $09: 00-22: 00$ & $\mathrm{~h}$ \\
Refrigerant charge (R404a) & 4.00 & $\mathrm{~kg} / \mathrm{kW}$ \\
HVAC system typology & Centralized DX & - \\
SCOP- Heating & 2.00 & - \\
SEER- Cooling & 2.50 & - \\
Illuminance & 500 & $\mathrm{lux}$ \\
Illumination technology & Metal Halide (MH) & - \\
Service life & 50 & Years \\
\hline
\end{tabular}


Table 2. Production phase main LCI

\begin{tabular}{|c|c|c|c|}
\hline Component & Materials & Amount & Units \\
\hline \multirow[t]{7}{*}{ External wall } & Concrete block & 215,457 & kg \\
\hline & Cement for bricklaying & 35,597 & $\mathrm{~kg}$ \\
\hline & Gypsum plaster board & 18,727 & $\mathrm{~kg}$ \\
\hline & Laminated steel profiles & 390 & $\mathrm{~kg}$ \\
\hline & Metal sheet & 6,967 & $\mathrm{~kg}$ \\
\hline & Cement mortar coat & 7,634 & $\mathrm{~kg}$ \\
\hline & Ceramic tiles & 10,992 & $\mathrm{~kg}$ \\
\hline \multirow[t]{3}{*}{ Adiabatic wall } & Hollow brick (double) & 13,156 & $\mathrm{~kg}$ \\
\hline & Gypsum & 4,068 & $\mathrm{~kg}$ \\
\hline & Cement for bricklaying & 3,607 & $\mathrm{~kg}$ \\
\hline \multirow[t]{9}{*}{ Internal wall } & Gypsum & 2,160 & $\mathrm{~kg}$ \\
\hline & Concrete block & 62,762 & $\mathrm{~kg}$ \\
\hline & Cement for bricklaying & 16,753 & $\mathrm{~kg}$ \\
\hline & Stainless steel sheet & 2,275 & $\mathrm{~kg}$ \\
\hline & PUR & 576 & $\mathrm{~kg}$ \\
\hline & Mortar coat & 14,140 & $\mathrm{~kg}$ \\
\hline & Ceramic block & 35,162 & $\mathrm{~kg}$ \\
\hline & Stoneware coating & 5,966 & $\mathrm{~kg}$ \\
\hline & Adhesive mortar & 4,203 & $\mathrm{~kg}$ \\
\hline \multirow[t]{5}{*}{ External and internal openings } & Glass 4.6 .4 (windows) & 71.75 & $\mathrm{~m}^{2}$ \\
\hline & Glass 6+6 (doors) & 7.00 & Units \\
\hline & Aluminium & 7.50 & $\mathrm{~m}^{2}$ \\
\hline & Roller door & 142.00 & $\mathrm{~kg}$ \\
\hline & Timber & 16.80 & $\mathrm{~m}^{2}$ \\
\hline \multirow[t]{5}{*}{ Ground foundation } & Stoneware & 41,250 & $\mathrm{~kg}$ \\
\hline & Adhesive mortar & 29,062 & $\mathrm{~kg}$ \\
\hline & Reinforced concrete slab & $1,150,000$ & $\mathrm{~kg}$ \\
\hline & Poor concrete & 275,000 & $\mathrm{~kg}$ \\
\hline & Stone (gravel and sand) & $1,000,000$ & $\mathrm{~kg}$ \\
\hline \multirow[t]{4}{*}{ Pitched roof } & Metal sheet & 17,775 & $\mathrm{~kg}$ \\
\hline & Waterproofing layer & 24,750 & $\mathrm{~kg}$ \\
\hline & Rock wool & 15,750 & $\mathrm{~kg}$ \\
\hline & Laminated plaster & 27,000 & $\mathrm{~kg}$ \\
\hline \multirow[t]{7}{*}{ Flat roof } & Stoneware & 6,250 & $\mathrm{~kg}$ \\
\hline & Adhesive mortar & 4,125 & $\mathrm{~kg}$ \\
\hline & Lightweight concrete & 12,000 & $\mathrm{~kg}$ \\
\hline & Waterproofing layers & 5,500 & $\mathrm{~kg}$ \\
\hline & Rock wool & 1,750 & $\mathrm{~kg}$ \\
\hline & Concrete slab & 62,000 & $\mathrm{~kg}$ \\
\hline & Gypsum & 3,750 & $\mathrm{~kg}$ \\
\hline \multirow[t]{3}{*}{ Structure and foundations } & Vertical structure HEB-240 & 21,565 & $\mathrm{~kg}$ \\
\hline & Laminated steel beams & 14,490 & $\mathrm{~kg}$ \\
\hline & Footings & 79,200 & $\mathrm{~kg}$ \\
\hline \multirow[t]{3}{*}{ Installations } & DHW electric boiler & 50 & l \\
\hline & Heat pump (DX) & 200 & $\mathrm{~kW}$ \\
\hline & Initial refrigerant charge R404a & 800.00 & $\mathrm{~kg}$ \\
\hline
\end{tabular}


Table 3. Construction phase main LCI

\begin{tabular}{lcc}
\hline \multicolumn{1}{c}{ Item } & Value & Unit $^{1}$ \\
\hline Electricity, low voltage & 6.73 & $\mathrm{kWh} / \mathrm{m}^{2}$ \\
Diesel, burned in building machine & 23.4 & $\mathrm{MJ} / \mathrm{m}^{2}$ \\
Tap water & 120 & $\mathrm{~kg} / \mathrm{m}^{2}$ \\
Transport to site & (Depending on material) & $\mathrm{tkm}$ \\
\hline
\end{tabular}

${ }^{1} \mathrm{~m}^{2}$ in construction phase refers to gross surface 
Table 4. Use phase main LCI

\begin{tabular}{lcc}
\hline \multicolumn{1}{c}{ Item } & Value & Unit \\
\hline Electricity, low voltage & 511 & $\mathrm{kWh} / \mathrm{m}^{2}$ year \\
Tap water & 2,000 & $\mathrm{l} / \mathrm{m}^{2}$ year \\
Annual Refrigerant Leakage & 20 & $\%$ \\
HVAC\&R EOL refrigerant leakage & 15 & $\%$ \\
\hline
\end{tabular}


Table 5. LCA results for the reference building

\begin{tabular}{cccc}
\hline & $\begin{array}{c}\text { Primary energy } \\
\text { demand } \\
\mathrm{MJ} \mathrm{eq} / \mathrm{m}^{2} \mathrm{year}\end{array}$ & $\begin{array}{c}\text { Global Warming } \\
\text { Potential } \\
\mathrm{kgCO}_{2}-\mathrm{eq} / \mathrm{m}^{2} \mathrm{year}\end{array}$ & $\begin{array}{c}\text { Water demand } \\
\mathrm{l} / \mathrm{m}^{2} \mathrm{year}\end{array}$ \\
\hline Production phase & $1.48 \mathrm{E}+02$ & $1.23 \mathrm{E}+01$ & $1.73 \mathrm{E}+02$ \\
Construction phase & $6.31 \mathrm{E}+00$ & $3.49 \mathrm{E}-01$ & $7.21 \mathrm{E}+00$ \\
Use phase & $6.24 \mathrm{E}+03$ & $6.91 \mathrm{E}+02$ & $1.61 \mathrm{E}+04$ \\
EOL phase & $1.54 \mathrm{E}+01$ & $2.89 \mathrm{E}+01$ & $1.29 \mathrm{E}+01$ \\
\hline Total & $6.41 \mathrm{E}+03$ & $7.32 \mathrm{E}+02$ & $1.63 \mathrm{E}+04$ \\
\hline
\end{tabular}


Table 6. Variations proposed

\begin{tabular}{llll}
\hline & \multicolumn{1}{c}{ Reference building } & \multicolumn{1}{c}{ Variation } \\
\hline Location of the store & Stand-alone building & Premise in a building \\
\hline Opening hours & $\begin{array}{l}\text { 13 h/day- 6 days a week } \\
(4,056 \text { hours/year) }\end{array}$ & $>\begin{array}{l}\text { 24 h/day- 7 days a week } \\
(8,760 \text { hours/year) }\end{array}$ \\
\hline & Charge: $4 \mathrm{~kg} / \mathrm{kW}$ & Charge: $0.4 \mathrm{~kg} / \mathrm{kW}$ \\
Refrigerant & Annual leakage (20\%) and & $>$ Annual leakage(15\%) and \\
& EOL leakage (15\%) & EOL leakage (10\%) \\
& R404a & $>$ R744 \\
\hline
\end{tabular}


Table 7. Scenarios considered

\begin{tabular}{|c|c|c|c|c|}
\hline & $\begin{array}{c}\text { Reference } \\
\text { Building }\end{array}$ & $\begin{array}{c}\text { Proposal } \\
1\end{array}$ & $\begin{array}{c}\text { Proposal } \\
2\end{array}$ & $\begin{array}{c}\text { Proposal } \\
3\end{array}$ \\
\hline Metal deck with bitumen coating & $\mathrm{x}$ & & & \\
\hline Metal deck without bitumen coating & & $\mathrm{x}$ & $\mathrm{x}$ & $\mathrm{x}$ \\
\hline $\begin{array}{l}\text { Metal Halide lighting } \\
\end{array}$ & $\mathrm{x}$ & & & \\
\hline Fluorescent lighting & & $\mathrm{x}$ & & \\
\hline LED technology lighting & & & $\mathrm{x}$ & $\mathrm{x}$ \\
\hline Skylights and dimming control & & & & $\mathrm{x}$ \\
\hline$-25 \mathrm{~W} / \mathrm{m}^{2}$ refrigeration thermal losses & $\mathrm{x}$ & & & \\
\hline$-20 \mathrm{~W} / \mathrm{m}^{2}$ refrigeration thermal losses & & $\mathrm{x}$ & $\mathrm{x}$ & $\mathrm{x}$ \\
\hline No wall insulation & $\mathrm{x}$ & $\mathrm{x}$ & & \\
\hline Wall insulation (MW 0.080 m) & & & $\mathrm{x}$ & $\mathrm{x}$ \\
\hline Air tightness ( 0.700 ach) & $\mathrm{x}$ & $\mathrm{x}$ & $\mathrm{x}$ & \\
\hline Air tightness ( 0.500 ach) & & & & $\mathrm{x}$ \\
\hline Heat recovery & & & $\mathrm{x}$ & $\mathrm{x}$ \\
\hline Free cooling & & & $\mathrm{x}$ & $\mathrm{x}$ \\
\hline Ground Source Heat Pump (GSHP) & & & & $\mathrm{x}$ \\
\hline
\end{tabular}


Table 8. Environmental net benefits of the scenarios proposed

\begin{tabular}{ccccc}
\hline & & $\begin{array}{c}\text { Primary energy } \\
\text { demand } \\
\mathrm{MJ} \mathrm{eq} / \mathrm{m}^{2} \mathrm{year}\end{array}$ & $\begin{array}{c}\text { Global Warming } \\
\text { Potential } \\
\mathrm{kgCO} \text { eq } / \mathrm{m}^{2} \mathrm{year}\end{array}$ & $\begin{array}{c}\text { Water demand } \\
1 / \mathrm{m}^{2} \mathrm{year}\end{array}$ \\
\hline \multirow{3}{*}{ Benefits } & Proposal 1 & $1.03 \mathrm{E}+03$ & $5.19 \mathrm{E}+01$ & $2.25 \mathrm{E}+03$ \\
& Proposal 2 & $1.80 \mathrm{E}+03$ & $8.98 \mathrm{E}+01$ & $3.96 \mathrm{E}+03$ \\
& Proposal 3 & $2.98 \mathrm{E}+03$ & $1.48 \mathrm{E}+02$ & $6.58 \mathrm{E}+03$ \\
\hline
\end{tabular}

Comentado [BGF1]: Revisar valores 
Table 9. LCA results for supermarket located in a premise $\left(\mathrm{kgCO}_{2}-\mathrm{eq} / \mathrm{m}^{2} \mathrm{year}\right)$

\begin{tabular}{cccccc}
\hline & $\begin{array}{c}\text { Reference } \\
\text { building }\end{array}$ & $\begin{array}{c}\text { Location } \\
\text { (Base) }\end{array}$ & $\begin{array}{c}\text { Location } \\
\text { (Proposal 1) }\end{array}$ & $\begin{array}{c}\text { Location } \\
\text { (Proposal 2) }\end{array}$ & $\begin{array}{c}\text { Location } \\
\text { (Proposal 3) }\end{array}$ \\
\hline $\begin{array}{c}\text { Production } \\
\text { phase }\end{array}$ & $1.23 \mathrm{E}+01$ & $1.18 \mathrm{E}+01$ & $1.17 \mathrm{E}+01$ & $1.18 \mathrm{E}+01$ & $1.18 \mathrm{E}+01$ \\
$\begin{array}{c}\text { Construction } \\
\text { phase }\end{array}$ & $3.49 \mathrm{E}-01$ & $3.23 \mathrm{E}-01$ & $3.21 \mathrm{E}-01$ & $3.67 \mathrm{E}-01$ & $3.67 \mathrm{E}-01$ \\
$\begin{array}{c}\text { Use } \\
\text { phase }\end{array}$ & $6.91 \mathrm{E}+02$ & $6.86 \mathrm{E}+02$ & $6.34 \mathrm{E}+02$ & $6.01 \mathrm{E}+02$ & $5.51 \mathrm{E}+02$ \\
$\begin{array}{c}\text { EOL } \\
\text { phase }\end{array}$ & $2.89 \mathrm{E}+01$ & $2.84 \mathrm{E}+01$ & $2.80 \mathrm{E}+01$ & $2.80 \mathrm{E}+01$ & $2.80 \mathrm{E}+01$ \\
\hline Total & $\mathbf{7 . 3 2 E + 0 2}$ & $\mathbf{7 . 2 7 E + 0 2}$ & $\mathbf{6 . 7 4 E + 0 2}$ & $\mathbf{6 . 4 2 E + 0 2}$ & $\mathbf{5 . 9 1 E + 0 2}$ \\
\hline
\end{tabular}


Table 10. LCA results for supermarket opened $24 \mathrm{~h}$ per day- 7 days per week $\left(\mathrm{kgCO}_{2}\right.$ eq/m² year)

\begin{tabular}{cccccc}
\hline & $\begin{array}{c}\text { Reference } \\
\text { building }\end{array}$ & $\begin{array}{c}\text { Schedule } \\
\text { ( Base ) }\end{array}$ & $\begin{array}{c}\text { Schedule } \\
\text { (Proposal 1) }\end{array}$ & $\begin{array}{c}\text { Schedule } \\
\text { (Proposal 2) }\end{array}$ & $\begin{array}{c}\text { Schedule } \\
\text { (Proposal 3) }\end{array}$ \\
\hline $\begin{array}{c}\text { Production } \\
\text { phase }\end{array}$ & $1.23 \mathrm{E}+01$ & $1.23 \mathrm{E}+01$ & $1.21 \mathrm{E}+01$ & $1.22 \mathrm{E}+01$ & $1.22 \mathrm{E}+01$ \\
$\begin{array}{c}\text { Construction } \\
\text { phase }\end{array}$ & $3.49 \mathrm{E}-01$ & $3.49 \mathrm{E}-01$ & $3.46 \mathrm{E}-01$ & $3.31 \mathrm{E}-01$ & $3.31 \mathrm{E}-01$ \\
$\begin{array}{c}\text { Use } \\
\text { phase }\end{array}$ & $6.91 \mathrm{E}+02$ & $7.62 \mathrm{E}+02$ & $6.93 \mathrm{E}+02$ & $6.37 \mathrm{E}+02$ & $5.71 \mathrm{E}+02$ \\
$\begin{array}{c}\text { EOL } \\
\text { phase }\end{array}$ & $2.89 \mathrm{E}+01$ & $2.89 \mathrm{E}+01$ & $2.82 \mathrm{E}+01$ & $2.82 \mathrm{E}+01$ & $2.82 \mathrm{E}+01$ \\
\hline Total & $\mathbf{7 . 3 2 E + 0 2}$ & $\mathbf{8 . 0 4 E + 0 2}$ & $\mathbf{7 . 3 4 E + 0 2}$ & $\mathbf{6 . 7 8 E}+\mathbf{0 2}$ & $\mathbf{6 . 1 2 E}+\mathbf{0 2}$ \\
\hline
\end{tabular}


Table 11. LCA results for supermarket with refrigerant modifications. $\left(\mathrm{kgCO}_{2}-\right.$ eq/m²year) i) Indirect system. (R404a charge: $0.4 \mathrm{~kg} / \mathrm{kW}$; R744 charge: $4.0 \mathrm{~kg} / \mathrm{kW}$ ); ii) Leakages minimization (ALR= 15\%; EOL=10\%); iii) Refrigerant substitution. R744 charge: $4.0 \mathrm{~kg} / \mathrm{kW}$

\begin{tabular}{|c|c|c|c|c|c|}
\hline & $\begin{array}{c}\text { Reference } \\
\text { building }\end{array}$ & $\begin{array}{l}\text { Refrigerant i } \\
\text { (Base) }\end{array}$ & $\begin{array}{r}\text { Refrigerant i } \\
\text { (Proposal 1) }\end{array}$ & $\begin{array}{c}\text { Refrigerant i } \\
\text { (Proposal 2) }\end{array}$ & $\begin{array}{c}\text { Refrigerant i } \\
\text { (Proposal 3) }\end{array}$ \\
\hline $\begin{array}{l}\text { Production } \\
\text { phase }\end{array}$ & $1.23 \mathrm{E}+01$ & $1.11 \mathrm{E}+01$ & $1.09 \mathrm{E}+01$ & $1.10 \mathrm{E}+01$ & $1.11 \mathrm{E}+01$ \\
\hline $\begin{array}{l}\text { Construction } \\
\text { phase }\end{array}$ & 3.49E-01 & 3.49E-01 & 3.46E-01 & 3.31E-01 & 3.31E-01 \\
\hline $\begin{array}{l}\text { Use } \\
\text { phase }\end{array}$ & $6.91 \mathrm{E}+02$ & $3.49 \mathrm{E}+02$ & $2.98 \mathrm{E}+02$ & $2.60 \mathrm{E}+02$ & $2.01 \mathrm{E}+02$ \\
\hline $\begin{array}{l}\text { EOL } \\
\text { phase }\end{array}$ & $2.89 \mathrm{E}+01$ & $4.31 \mathrm{E}+00$ & $3.59 \mathrm{E}+00$ & $3.59 \mathrm{E}+00$ & $3.59 \mathrm{E}+00$ \\
\hline \multirow[t]{2}{*}{ Total } & $7.32 \mathrm{E}+02$ & $3.64 \mathrm{E}+02$ & 3.12E+02 & $2.74 \mathrm{E}+02$ & $2.16 \mathrm{E}+02$ \\
\hline & $\begin{array}{l}\text { Reference } \\
\text { building }\end{array}$ & $\begin{array}{l}\text { Refrigerant ii } \\
\text { (Base) }\end{array}$ & $\begin{array}{c}\text { Refrigerant ii } \\
\text { (Proposal 1) }\end{array}$ & $\begin{array}{c}\text { Refrigerant ii } \\
\text { (Proposal 2) }\end{array}$ & $\begin{array}{c}\text { Refrigerant ii } \\
\text { (Proposal 3) }\end{array}$ \\
\hline $\begin{array}{l}\text { Production } \\
\text { phase }\end{array}$ & $1.23 \mathrm{E}+01$ & $1.63 \mathrm{E}+01$ & $1.61 \mathrm{E}+01$ & $1.62 \mathrm{E}+01$ & $1.63 \mathrm{E}+01$ \\
\hline $\begin{array}{l}\text { Construction } \\
\text { phase }\end{array}$ & 3.49E-01 & 3.49E-01 & 3.46E-01 & 3.31E-01 & 3.31E-01 \\
\hline $\begin{array}{l}\text { Use } \\
\text { phase }\end{array}$ & $6.91 \mathrm{E}+02$ & $5.97 \mathrm{E}+02$ & $5.46 \mathrm{E}+02$ & $5.08 \mathrm{E}+02$ & $4.49 \mathrm{E}+02$ \\
\hline $\begin{array}{l}\text { EOL } \\
\text { phase }\end{array}$ & $2.89 \mathrm{E}+01$ & $1.98 \mathrm{E}+01$ & $1.91 \mathrm{E}+01$ & $1.91 \mathrm{E}+01$ & $1.91 \mathrm{E}+01$ \\
\hline \multirow[t]{2}{*}{ Total } & $7.32 \mathrm{E}+02$ & $6.33 \mathrm{E}+02$ & $5.81 E+02$ & $5.43 \mathrm{E}+02$ & $4.85 E+02$ \\
\hline & $\begin{array}{c}\text { Reference } \\
\text { building }\end{array}$ & $\begin{array}{c}\text { Refrigerant } \\
\text { iii } \\
\text { ( Base) }\end{array}$ & $\begin{array}{c}\text { Refrigerant } \\
\text { iii } \\
\text { (Proposal 1) }\end{array}$ & $\begin{array}{c}\text { Refrigerant } \\
\text { iii } \\
\text { (Proposal 2) }\end{array}$ & $\begin{array}{c}\text { Refrigerant } \\
\text { iii } \\
\text { (Proposal 3) }\end{array}$ \\
\hline $\begin{array}{l}\text { Production } \\
\text { phase }\end{array}$ & $1.23 \mathrm{E}+01$ & $1.09 \mathrm{E}+01$ & $1.08 \mathrm{E}+01$ & $1.08 \mathrm{E}+01$ & $1.09 \mathrm{E}+01$ \\
\hline $\begin{array}{l}\text { Construction } \\
\text { phase }\end{array}$ & 3.49E-01 & 3.49E-01 & 3.46E-01 & 3.31E-01 & 3.31E-01 \\
\hline $\begin{array}{l}\text { Use } \\
\text { phase }\end{array}$ & $6.91 \mathrm{E}+02$ & $3.11 \mathrm{E}+02$ & $2.59 \mathrm{E}+02$ & $2.21 \mathrm{E}+02$ & $1.63 \mathrm{E}+02$ \\
\hline $\begin{array}{l}\text { EOL } \\
\text { phase }\end{array}$ & $2.89 \mathrm{E}+01$ & $1.57 \mathrm{E}+00$ & 8.60E-01 & 8.60E-01 & 8.60E-01 \\
\hline Total & $7.32 \mathrm{E}+02$ & $3.23 E+02$ & $2.71 E+02$ & $2.34 \mathrm{E}+02$ & $1.75 E+02$ \\
\hline
\end{tabular}


Table 12. DLCA selected variables

\begin{tabular}{|c|c|c|c|}
\hline Level & Category & Variable & Cause \\
\hline LCI & Building operation & Energy consumption & $\begin{array}{c}\text { Annual refrigerant } \\
\text { leakages and maintenance } \\
\text { operation }\end{array}$ \\
\hline \multirow{2}{*}{ LCI } & Cunnlyolin drmomice & 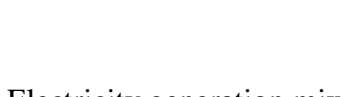 & $\begin{array}{l}\text { EU trends and objectives } \\
\text { towards 2020, 2030, } 2050\end{array}$ \\
\hline & & & Site \\
\hline LCI & Inventory dynamics & Type of refrigerant & F-Gas regulation \\
\hline LCIA & $\begin{array}{c}\text { Environmental system } \\
\text { dynamics }\end{array}$ & Not evaluated & Not evaluated \\
\hline
\end{tabular}


Table 13. Review of energy consumption rise due to refrigerant leakages

\begin{tabular}{|c|c|c|c|c|c|}
\hline Source & Refrigerant & Energy eff & ficiency & $\begin{array}{c}\text { Undercharge } \\
\text { level }\end{array}$ & Conditions \\
\hline \multirow{4}{*}[60]{} & \multirow{4}{*}{$\mathrm{R}-22$} & \multirow{4}{*}{ SEER } & $-5 /-10 \%$ & $-10 \%$ & 5 systems with and \\
\hline & & & $-10 /-20 \%$ & $-20 \%$ & without accumulator \\
\hline & & & $-15 /-20 \%$ & $-30 \%$ & (Dry) Outdoor temp $=35^{\circ} \mathrm{C}$ \\
\hline & & & $-30 /-40 \%$ & $-40 \%$ & (Dry) Indoor temp $=27^{\circ} \mathrm{C}$ \\
\hline \multirow[b]{2}{*}{ [61] } & \multirow{2}{*}{ R404a } & \multirow[b]{2}{*}{$\mathrm{COP}$} & $-5 \%$ & $-25 \%$ & Small chiller. \\
\hline & & & $-45 \%$ & $-50 \%$ & $\begin{array}{c}\text { Condenser coolant temp }= \\
30-35^{\circ} \mathrm{C}\end{array}$ \\
\hline \multirow{3}{*}{ [62] } & \multirow{3}{*}{$\begin{array}{l}\text { R410 } \\
\text { \&R134 }\end{array}$} & \multirow{3}{*}{$\mathrm{COP}$} & $-10 \%$ & $-4 \%$ & Cascade system. \\
\hline & & & & & Ambient temp $=7^{\circ} \mathrm{C}$; \\
\hline & & & $-20 \%$ & $-8 \%$ & $\begin{array}{l}\text { Compressor speed= } \\
2700 \mathrm{rpm}\end{array}$ \\
\hline \multirow{6}{*}{ [63] } & \multirow{2}{*}{ R22 } & \multirow{6}{*}{ COP } & $-2 \%$ & $-10 \%$ & \\
\hline & & & $-4 \%$ & $-20 \%$ & \\
\hline & & & $-5 \%$ & $-10 \%$ & $\mathrm{CO}_{2}$ transcritical. \\
\hline & R407c & & $-8 \%$ & $-20 \%$ & $\begin{array}{l}\text { Outdoor temp }=35 / 24^{\circ} \mathrm{C} \\
\text { Indoor temp }=27 / 19.5^{\circ} \mathrm{C}\end{array}$ \\
\hline & \multirow{2}{*}{$\mathrm{CO}_{2}$} & & $-10 \%$ & $-10 \%$ & \\
\hline & & & $-25 \%$ & $-20 \%$ & \\
\hline [25] & General & $\begin{array}{c}\text { Energy } \\
\text { consumption }\end{array}$ & $-10 /-15 \%$ & $\begin{array}{c}\text { Average } \\
\text { annual } \\
\text { supermarket } \\
\text { leakages }\end{array}$ & - \\
\hline
\end{tabular}


Table 14. Refrigerant undercharge assumptions

\begin{tabular}{|c|c|c|c|c|c|}
\hline $\begin{array}{l}\text { Annual } \\
\text { refrigerant } \\
\text { leakage }\end{array}$ & Refill & $\begin{array}{c}\text { Refrigerant } \\
\text { typology }\end{array}$ & \multicolumn{2}{|c|}{$\begin{array}{l}\text { Refrigerant } \\
\text { undercharge }\end{array}$} & $\begin{array}{c}\text { Energy } \\
\text { consumption } \\
\text { increase } \\
\end{array}$ \\
\hline \multirow{4}{*}{$20 \%$} & \multirow{4}{*}{ Every two years } & \multirow{2}{*}{ R404a } & year 1 & $20 \%$ & $+10 \%$ \\
\hline & & & year 2 & $40 \%$ & $+30 \%$ \\
\hline & & \multirow{2}{*}{$\mathrm{CO}_{2}$} & year 1 & $20 \%$ & $+20 \%$ \\
\hline & & & year 2 & $40 \%$ & $+50 \%$ \\
\hline
\end{tabular}


Table 15. DLCA results ( $\mathrm{kgCO}_{2}$-eq $/ \mathrm{m}^{2}$ year)

\begin{tabular}{|c|c|c|c|c|c|}
\hline \multirow{2}{*}{ Electricity mix } & $\begin{array}{l}\text { Non-time- } \\
\text { dependant }\end{array}$ & $\begin{array}{c}\text { Time- } \\
\text { dependant }\end{array}$ & $\begin{array}{c}\text { Time- } \\
\text { dependant }\end{array}$ & $\begin{array}{c}\text { Time- } \\
\text { dependant }\end{array}$ & $\begin{array}{c}\text { Time- } \\
\text { dependant }\end{array}$ \\
\hline & EU average & Spain & EU average & Spain & EU average \\
\hline Refrigerant & R404a & R404a & R404a & R744 & R744 \\
\hline $\begin{array}{l}\text { Production } \\
\text { phase }\end{array}$ & $1.23 \mathrm{E}+01$ & $1.23 \mathrm{E}+01$ & $1.23 \mathrm{E}+01$ & $1.10 \mathrm{E}+01$ & $1.10 \mathrm{E}+01$ \\
\hline $\begin{array}{l}\text { Construction } \\
\text { phase }\end{array}$ & 3.49E-01 & 3.49E-01 & 3.49E-01 & 3.49E-01 & 3.49E-01 \\
\hline $\begin{array}{l}\text { Use } \\
\text { phase }\end{array}$ & $6.24 \mathrm{E}+02$ & $5.49 \mathrm{E}+02$ & $5.81 \mathrm{E}+02$ & $1.84 \mathrm{E}+02$ & $2.19 \mathrm{E}+02$ \\
\hline $\begin{array}{l}\text { EOL } \\
\text { phase }\end{array}$ & $2.89 \mathrm{E}+01$ & $2.89 \mathrm{E}+01$ & $2.89 \mathrm{E}+01$ & $1.57 \mathrm{E}+00$ & 7.38E-03 \\
\hline Total & $6.65 E+02$ & $5.90 \mathrm{E}+02$ & $6.23 E+02$ & $1.96 E+02$ & $2.31 E+02$ \\
\hline
\end{tabular}

